\title{
Do mergers and acquisitions increase default risk? Evidence from the European market
}

\author{
Wolfgang BESSLER, Hidde STEENBEEK, Wim WESTERMAN \\ University of Groningen, The Netherlands
}

\section{Abstract:}

Aim: In this study, we examine the changes in default risk of the bidder over the course of a merger or acquisition. The data set consists of 531 deals in which the acquirers are European firms. We employ a general set of determinants to analyse the change in default risk and extend the literature by providing new empirical evidence for the European capital market.

Research design: Abnormal returns are analysed to provide preliminary insights into the merger induced valuation effects. All hypothesized relationships on the changes in default risk are tested via a regression analysis. We differentiate these results further by analysing which factors determine the increase in default risk.

Findings: Previous research on this issue reported mixed results. The main finding of our empirical analysis is that, on average, mergers and acquisitions of European bidders significantly increase default risk during the post-merger period.

Originality: This study adds to the mergers and acquisitions literature for European bidders and targets. The empirical findings suggest that some observed relationships and determinants are different in Europe than in the United States.

Implications: This research introduces a default risk model that could be applied to predict bidder performance subsequent to a merger or acquisition by analysing possible changes in default risk of the bidder. It also provides some possible explanations for the average increase in default risk. This study may help practitioners to better assess the potential risks when acquiring other firms.

Key words: mergers \& acquisitions, abnormal returns, default risk, Europe

$J E L: \mathrm{G} 32, \mathrm{G} 34$

Correspondence address: Wolfgang Bessler, Faculty of Economics and Business, University of Groningen, The Netherlands, E-mail, w.h.bessler@rug.nl. Hidde Steenbeek, Faculty of Economics and Business, University of Groningen, The Netherlands, E-mail: hidde.steenbeek@hotmail.com. Wim Westerman, Faculty of Economics and Business, University of Groningen, The Netherlands, E-mail, w.westerman@rug.nl.

Received: 20.11.2019, Revised: 11.12.2019, Accepted: 16.12.2019

doi: http://dx.10.29015/cerem.861 


\section{Introduction}

The total deal value of global mergers and acquisitions (M\&As) is at its highest level since 2015 and the average deal value has been increasing since the global financial crisis of 2008 (Bureau van Dijk 2018). Mergers and acquisitions have advanced to become one of the most important growth strategies in many industries and for many firms, small and large, resulting in less firms being publicly listed (Lattanzio et al. 2019). Nevertheless, merging with or acquiring other firms has always been risky as the outcome can either be value enhancing or value destroying for the shareholder of the bidder, and it is not obvious in advance which outcome will occur. Therefore, the objective of this study is to examine the effects that a corporate merger or acquisition has on the default probability of the acquirer. Previous academic studies combining the research on default risk and M\&As is rather limited and provides at best ambiguous results. As usual, most M\&A research primarily focusses on the United States, whereas a lack of research exists for other regions. Consequently, our study investigates the European market. The outcome of this research might be of interest to managers of bidder and target firms, investors and corporate finance advisors alike, as a firm's change in default risk after acquiring another firm is clearly of essential importance.

Default or bankruptcy of a firm is defined in legal terms as the moment the firm can no longer pay its debt. In technical terms, this is the case when the liabilities become larger than the assets of a firm, resulting in negative equity. There are a number of different approaches to estimate and predict the default probability of a firm. The Merton distance to default model (Merton 1974), an adaptation of the Black and Scholes (1973) option pricing model, is an approach to estimate the default risk. The distance to default is a measure for how far away a firm is from defaulting on its liabilities, making it inversely related to default risk. The Merton model assumes efficient financial markets, which is a reasonable assumption for European capital markets and our research. In this study, we apply the Merton model and use the Altman Z''-score (Altman et al. 2014) as a robustness check.

In our analysis, we first examine for a European data set the valuation effects of bidders and targets involved in an acquisition for the period surrounding the 
announcement and then analyse the determinants explaining the magnitude of these effects. This leads to the research question of this article, especially how a merger and acquisition affect the default risk of the bidder after deal completion. Previous research on this topic has provided mixed outcomes on both separate samples and partially overlapping ones (Koerniadi et al. 2015; Maksimovna 2015). This ambiguity can be due to multiple reasons, for example, restrictions on the sample size and sample period of these studies.

The aim of this research is to employ a general set of determinants including some sample requirements to extend the research on this topic and to provide new findings for the European capital market. The research involves a sample of 531 deals by European acquiring firms that were completed between October 1998 and March 2018. We find support for the idea that distance to default is significantly related to the size of the valuation effects. Moreover, we create a uniform model that provides empirical evidence for a significant influence of several determinants on the acquirer's default risk subsequent to a merger or acquisition. For this, we employ various analyses for the full sample and for various subsamples. Overall, this research adds new insights to the previous literature and to specific topics such as the firm's distance to default, market valuations, and relative size.

This article continues as follows. First, we provide a review of the literature on mergers and acquisitions. The methodology section outlines our research strategy followed by the data and our descriptive statistics. Subsequently, we discuss the results in terms of both valuation effects and change in default risk. Finally, we offer concluding remarks including the summary of the research and implications for practice as well as future research.

\section{Literature review and hypotheses}

In this section, we discuss the previous literature on the relationship between mergers and acquisitions and the financial valuation effects of the bidder and target firms. Our focus is especially on the relationship between M\&As and changes in 
default risk. Both topics are discussed along several major features, resulting in eight hypotheses.

$M \& A s$ and valuation effects. Hackbarth and Morellec (2008) suggest that for their sample of U.S. public takeovers between 1985 and 2002, the valuation effects in terms of cumulative abnormal returns surrounding the announcement period ( -1 day and +1 day) are on average substantial and significantly positive for the acquired firm (target). ${ }^{1}$ Alexandridis et al. (2010) study firms across the globe. They provide evidence for both a world-wide and a European subsample that target firms experience positive and highly significant abnormal returns during the period surrounding the M\&A announcement. Ishii and Xuan (2014) also find for a strictly US sample positive valuation effects for the target in the period surrounding the announcement. Tang and $\mathrm{Xu}$ (2016) report positive and significant abnormal returns for the target in the 5 days after the announcement date for their sample of mostly US deals. An explanation for these observations is that, on average, the acquirer has to pay a substantial premium for buying the shares of the target (Savor, Lu 2009). If markets are efficient, meaning that all M\&A related information is incorporated instantaneously and fully in the stock price, then there should be hardly any stock price reaction of the target before and after the announcement but only on the day when the deal becomes public knowledge. The size of the premium and the stock price reaction could depend on several factors, which we will explore later. Often, the size of this premium is based on possible synergy gains and most to nearly all synergy gains go to the target shareholders, resulting in positive valuation effects (Bessler, Schneck 2015, 2016). The finding that the target company's cumulative abnormal return (CAR) is positive and significant is also in line with the previous literature (Mitchell et al. 2001). The above-described findings and those from the literature are shown in Table 1 leading to the formulation of our first hypothesis.

\footnotetext{
${ }^{1}$ In this context, a valuation effect is an information induced change in the share price of a listed company. Abnormal returns are the risk adjusted percentage share price change minus the percentage price change of the overall market (Brown and Warner, 1985). Cumulative abnormal returns refer to the sum of abnormal returns. The calculation of this measure is explained in more detail in the methodology section.
} 
DO MERGERS AND ACQUISITIONS INCREASE DEFAULT RISK?

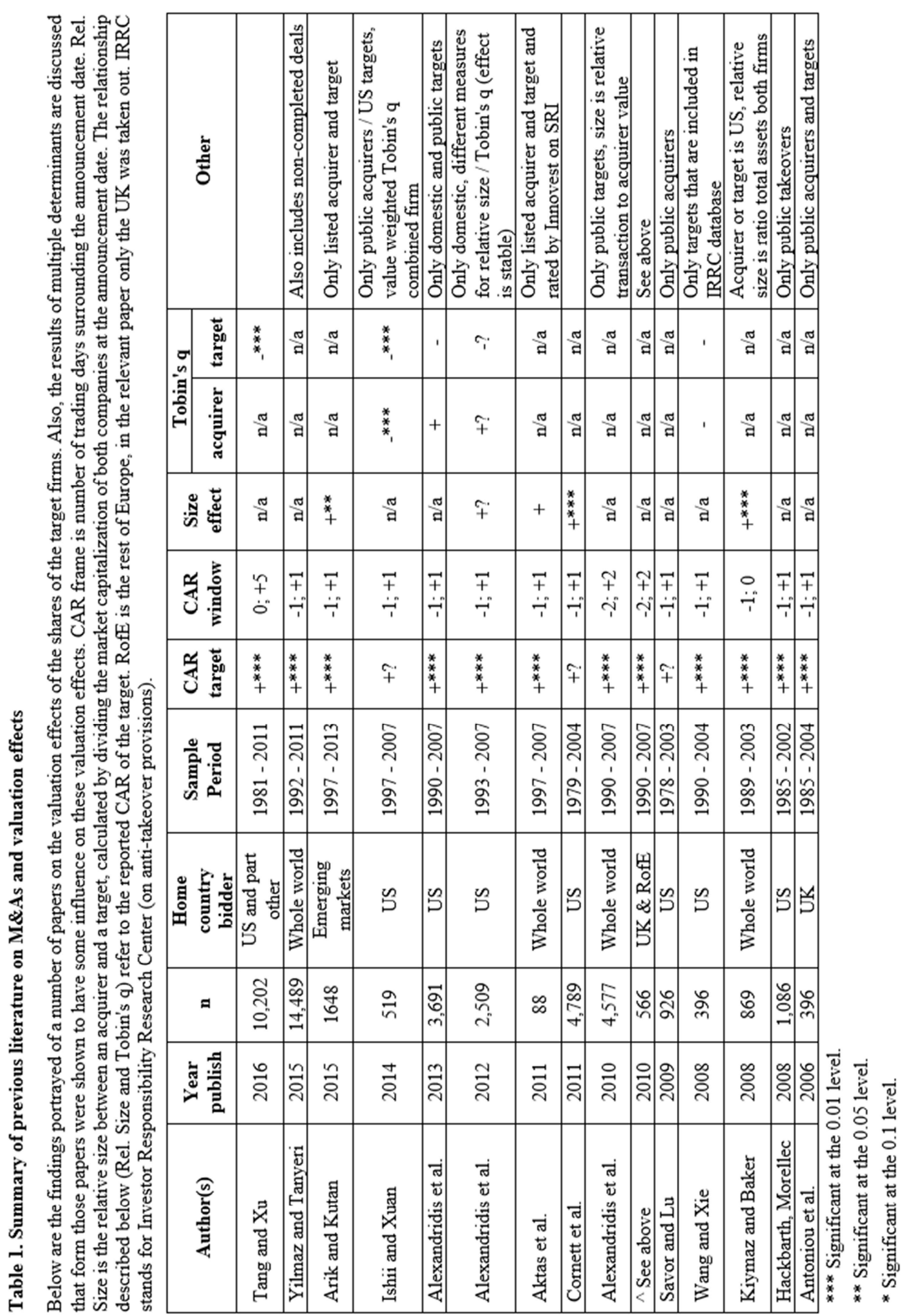


H1: In the period surrounding the announcement of an M\&A deal, there are positive valuation effects and positive abnormal returns for the target, meaning that the share price of the bidder increases by more than the appropriate benchmark.

The hypothesized relationship might be influenced by various variables, including the relative size between the acquiring firm and the target firm (Cornett et al. 2011). Moeller et al. (2004) were the first to provide support for a size effect on the valuation outcomes in M\&As. Arık and Kutan (2015) suggest that the relative size does indeed have a significant positive impact on the share price of the target. In these cases, the target is relatively smaller compared to the acquirer. Overall, there is, on average, a higher premium when the relative size of the acquirer increases, as the size of the premium and the money involved becomes less relevant for the acquirer.

There could be another economic intuition for explaining this relationship when the relative sizes changes. For cases where the target is relatively larger than the bidder, the integration into the smaller bidder may require more diligent integration work within the acquiring firm (Antoniou et al. 2008). There is empirical evidence that this relative size effects may only become relevant over time, but they are reflected in the target returns surrounding the M\&A announcement (Kiymaz, Baker 2008). In Table 1, we summarize the findings of various studies on this effect. Consequently, we formulate the second hypothesis as follows:

$\mathrm{H} 2$ : When the target is relatively smaller than the acquiring firm, its share price increase will be relatively higher in the period surrounding the announcement of an M\&A deal than for larger targets.

Another firm characteristic that may influence the size of the valuation effect during a merger or acquisition is Tobin's q, defined as a ratio between the market value of a firm's assets and the replacement value of the firm's assets (Tobin 1969). The Tobin's q can also be seen as a forward-looking proxy for how 'well' a firm is managed (Dezsö, Ross 2012). This means that a 'better' managed firm more effectively creates cash flows from its assets and therefore increases its market value (cf. Lang et al. 1989). In some of the previous literature, this measure is extended to relative Tobin's q (Alexandridis et al. 2012). A higher value of this measure indicates that the acquiring firm is 'better' managed and creates cash flows more efficiently than the target. Intuitively, this suggests that if the acquiring firm has superior 
management quality and is better managed than the target firm is, the latter will benefit from this superior management capacity and skills when the firms are combined through an M\&A. This could be interpreted as one form of synergies, resulting in a higher premium and a higher valuation effect of the target's shares.

Dong et al. (2006) indicate that the relative market-to-book ratios of the acquirer and the target may also influence the size of the premium and therefore the abnormal target returns. As before, there should be a positive relationship (Alexandridis et al. 2012) as possible synergies are expected to materialize when the bidder begins to manage the targets' assets. For example, when the acquiring firm is expected to create cash flows more efficiently than the target firm, given its asset base, the deal will create an immediate value gain for the shareholders of the target firm as the share price increases before the deal is completed (Wang, Xie 2008). In Table 1, we provide some additional results of the relationship between Tobin's $q$ and the abnormal returns. Many previous studies employed different variables as a proxy for Tobin's q, however, we focus on a different ratio in this study. Therefore, we report the results for most of the employed ratios so far. The insights from the previous literature lead to the formulation of the third hypothesis.

H3: The target's share price will increase relatively more in the period surrounding the announcement of an M\&A deal when the Tobin's q of the target is relatively lower than the Tobin's q of the acquiring firm and vice versa.

$M \& A s$ and default risk. As an exploratory step, it is interesting to understand whether the default risk of one or both firms involved in a deal have any influence on the magnitude of the valuation effects. It is essential to note that many variables affect the direction and size of the effect. One important variable is the method of payment used for a merger or acquisition as it influences the financial risk of the bidder. The alternatives are either paying with shares or cash or a combination of both. In a share deal, some risk is transferred from the bidder to the target shareholders. In a cash deal, the safe assets "cash" is exchanged for riskier assets or future cash flows of the target, hence, having bidder shareholders sharing in the full risk of the post-merger firm (Furfine, Rosen 2011). Financing of the deal can occur with either equity, debt or the firm's cash holdings. When financing the deal by issuing corporate bonds, there also occurs some risk transfer between the shareholders of the target and the acquirer 
(Billett et al. 2004). Overall, according to Bessler et al. (2011), it is important to analyse the deal by differentiating with respect to leverage and changes in leverage of the bidder, the employed financing instruments (cash, debt, or equity) as well as the method of payment (cash, shares and a combination). These are all important variables for analysing the bidders' post-merger change in default risk.

We now review and discuss the literature with respect to merger-induced changes in default risk. In our empirical analysis, we implement the Merton distance to default model as our main measure for default risk and changes in default risk. The distance to default is defined as how many standard deviations a firm is away from defaulting on its liabilities when concentrating on the distribution of the total asset values. Distance to default and default risk must be negatively correlated: the higher the distance to default, the lower is the default risk. So far, the literature using structural default risk models for analysing the changes in default risk from before to subsequent of a merger or acquisition is limited. The outcomes of the few studies so far are summarized in Table 2. Therefore, this research widens the scope of the M\&A literature on this topic although it is to some extent exploratory.

This research adds some new insights to the literature by focussing on European acquirers as well as on specific aspects, especially default risk. The basic idea is that mergers or acquisitions affect and change the default risk of the acquiring firm (Bruyland, De Maeseneire 2016), depending on the success of the firm subsequent to the acquisition. There are different reasons and explanations why the firm's default risk may decrease or increase or may be unaffected by the M\&A. Furfine and Rosen (2011) explain the negative effect with the observation that often the firms' leverage increases post-merger (Ghosh, Jain 2000), and most likely, a higher firm leverage increases the default risk. Even in the case when Furfine and Rosen (2011) control for the effect of leverage increases, they still find an increase in default risk subsequent to an M\&A deal. 
DO MERGERS AND ACQUISITIONS INCREASE DEFAULT RISK?

\begin{tabular}{|c|c|c|c|c|c|c|}
\hline 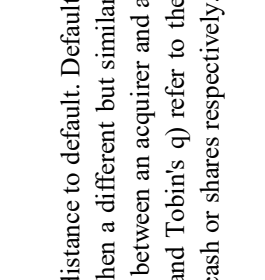 & 竧 & 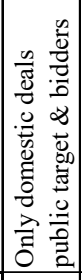 & & & 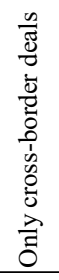 & 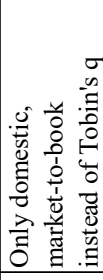 \\
\hline 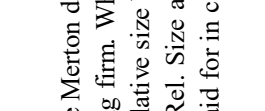 & 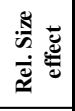 & $\dddot{+}$ & $\stackrel{\pi}{\Xi}$ & + & $\stackrel{\pi}{\Xi}$ & $\tilde{i}_{i}$ \\
\hline 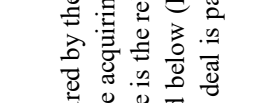 & 总言 & $\stackrel{\pi}{\Xi}$ & $\stackrel{\pi}{\Omega}$ & $\stackrel{\pi}{\Xi}$ & $\stackrel{\pi}{\Xi}$ & * \\
\hline 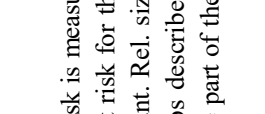 & 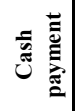 & $\Xi ี$ & $\stackrel{\pi}{=}$ & $\stackrel{*}{*}+$ & 菨 & 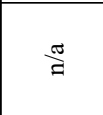 \\
\hline 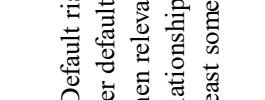 & 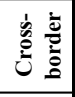 & $\Xi ّ$ & $\stackrel{\pi}{\Xi}$ & + & + & $\stackrel{\pi}{\Xi}$ \\
\hline & 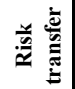 & $i$ & $\stackrel{*}{*}$ & $\stackrel{\pi}{\Xi}$ & $\stackrel{\pi}{\Xi}$ & $\stackrel{\pi}{\Xi}$ \\
\hline 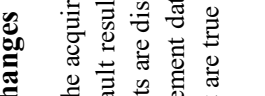 & 习ิ & $i_{i}$ & 宩 & * & $\dddot{+}$ & $i$ \\
\hline 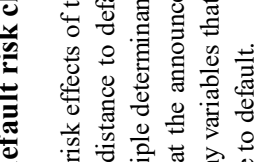 & 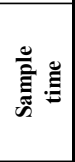 & 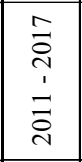 & 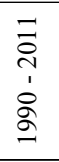 & 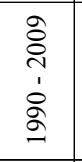 & 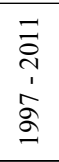 & 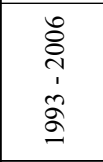 \\
\hline 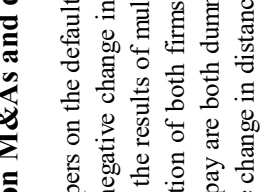 & 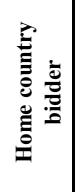 & 5 & $\tilde{s}$ & 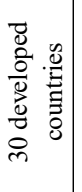 & 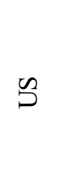 & 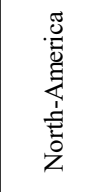 \\
\hline & $=$ & $\underset{\sim}{\infty}$ & $\stackrel{+}{=}$ & 心 & $\stackrel{n}{n}$ & 壱 \\
\hline 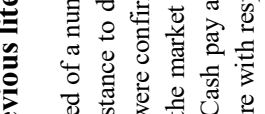 & 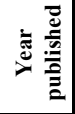 & $\stackrel{\infty}{\stackrel{\sim}{\sim}}$ & $\stackrel{\circ}{\stackrel{\sim}{े}}$ & $\stackrel{n}{\stackrel{\sim}{\sim}}$ & $\stackrel{n}{\stackrel{\sim}{N}}$ & $\vec{i}$ \\
\hline 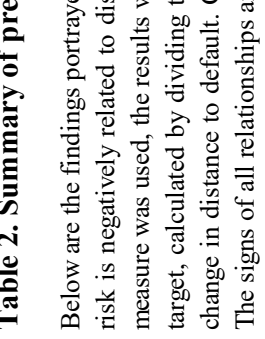 & 高 & 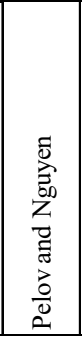 & 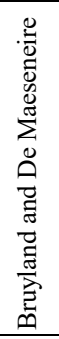 & 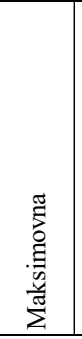 & 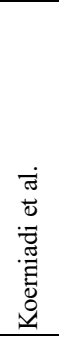 & 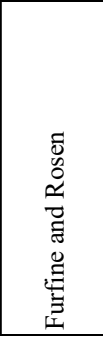 \\
\hline
\end{tabular}


Another starting point to analyse this increase in default risk, at least on average, is based on the idea to implement Merton's distance to default model that incorporates all consequences of equity mispricing (Liao et al. 2009). It is based on the notion that the agency problem of free cash flow (Jensen 1986) has a direct impact on how to judge the default risk of a firm (Maksimovna 2015). If managers have a free cash flow surplus, they will often make poor investments and suboptimal merger and acquisition decisions and consequently are not acting in the best interest of shareholders (Jensen 2005). In a preliminary study, Pelov and Nguyen (2018) aim to explain why some form of risk transfer occurs in a corporate environment. Billett et al. (2004) had already studied this issue for corporate bond issuances related to M\&As before. Similar results are also captured by Bruyland and De Maeseneire (2016). Therefore, we use and generalize these results for our research. Based on the previous studies and their empirical findings, we formulate our fourth hypothesis as follows.

H4: Mergers and acquisitions, on average, will increase the acquiring firm's default risk, implying a negative relationship with the change in distance to default.

One of the explanations for this increase in bidder's default risk is that the target has a higher default risk and it occurs some risk transfer when the target firm is merged with or acquired by the bidder. In this case, synergies and diversification effects may be less positive and, in some cases, may turn out to be negative. Prior research has already provided some support for this risk transfer by studying the response of corporate bond prices to an M\&A announcement. Results from Kedia and Zhou (2014) suggest that the target's bond price increased when the acquiring firm's bonds were higher rated than the bonds of the target company at the time of an acquisition. In this case, the yield required by bondholders after the M\&A is lower due to the higher quality of the bidder. These results are somewhat similar to those provided Billett et al. (2004).

There is also some kind of equity risk transfer in an M\&A process. For a U.S. M\&A sample, there is some evidence that the default risk increases more when the target is not in distress than when it is in distress (Bruyland, De Maeseneire 2016). A duplication of this study with a different sample led to similar results (Pelov, Nguyen 2018). Although this seems less sensible at first glance, there are examples that could lead to this outcome. First, when the cash flows of bidder and target are negatively 
correlated, resulting in lower risk when they are combined, resulting in a higher valuation. Second, when the target is in distress and the assets are extremely low valued, the acquisition could be a project with a positive net present value. Therefore, from a risk management perspective, it seems in some instances beneficial for the acquiring firm to acquire or merge with a distressed target. Therefore, for some deals the premium paid for such a target could be lower than that of a non-distressed target, resulting in a lower payment and possible lower increase in leverage but higher gains. The fifth hypothesis is therefore formulated as follows.

H5: In specific circumstances, there will be a larger increase in default risk of the bidder when the target is less risky and vice versa, implying a negative relationship with change in distance to default.

An additional aspect is that most research usually finds different outcomes between cross-border and domestic mergers (cf. Maksimovna 2015). Cross-border M\&A deals could contribute to the diversification of risk (Amihud, Lev 1981) and this should result in a decrease in default risk. This reasoning may explain the difference in the results of Furfine and Rosen (2011) and Koerniadi et al. (2015). The first study uses only US domestic M\&A's and finds, on average, an increase in default risk. The second study focusses only on US cross-border deals and provides evidence for an average decrease in default risk. In addition, when a new host country is more distant than a host country that is on the same continent, this might result in higher diversification opportunities. Consequently, the above reasoning leads to the following hypothesis.

H6: Change in distance to default of the acquirer will be positively related to geographical diversification, implying that there might be a decrease in default risk when the deal is cross-border and/or cross-continent and vice versa.

Another possible explanation for an increase in default risk, which we already indicated above, is the increase of post-merger leverage (Ghosh, Jain 2000). Whether this occurs or not depends on the financing of the deal and the method of payment that the acquirer employs. It is widely established that there are differences in valuation effects between different financing and payment methods due to different information asymmetries (Bessler et al. 2011). When an M\&A is paid for in cash, it is possible that the deal is financed by issuing additional debt (bonds), and therefore leverage and 
risk could increase (Furfine, Rosen 2011). However, it is also possible that for a cash deal the bidder either has accumulated cash or issued new equity before the deal announcement (Bessler et al. 2011). Nevertheless, agency problems imply that bidders pay with cash when a positive deal outcome is highly likely and with shares when the deal outcome is much riskier, sharing risk and possible losses with the target shareholders. Consequently, this also suggests that share deals are more likely to increase the bidders' default risk.

In contrast, another aspect is that since the acquirer is exchanging the safer liquid assets "cash" for the riskier future cash flows of the target company, default risk might increase (Furfine, Rosen 2011), especially when the deal outcome is risky. This relationship is supported by Koerniadi et al. (2015). In contrast, when the target is acquired by paying with shares (the bidder issues shares and transfers them to the target's shareholders for exchange of the target shares), there is usually no increase in leverage, but a decrease. Consequently, when paying with shares, the leverage of the bidder is seldom greater after deal completion, but typically the leverage decreases when new equity is issued, unless a high level of debt is assumed from the target. It is also possible that the bidder had increased the leverage during the period prior to the M\&A and now uses the equity offering (SEO) for the deal to adjust back to its optimal capital structure. Importantly, a steep increase in cash as a method of payment for M\&As was observed for different reasons during the last decade. We tend to follow the agency problem argument and state our hypothesis seven as follows.

H7: When in M\&As the target shareholders are at least partially paid for with shares, there will be a larger increase in default risk than with cash payments, indicating a negative relationship for share deals with changes in distance to default and a positive relationship for cash deals.

As already discussed, the relative firm size in a deal might affect the size of the valuation effect of a target firm (Asquith et al. 1983). In Table 2, numerous outcomes for this relationship are summarized. It seems that a positive relationship is supported, meaning that when the acquirer is relatively larger than the target, the increase of the default risk will be relatively smaller. Acquiring a smaller target might lead to a less complicated integration process then when buying a larger target (Antoniou et al. 2008). This results in the eighth and last hypothesis. 
H8: In M\&A's there will be larger increase in default risk when the target is relatively larger and vice versa, indicating a negative relationship with a change in distance to default.

\section{Methodology}

In this section, we introduce the methodology for measuring abnormal returns as well as the Merton's distance to default model and explain how we integrate these measures into our research. First, we analyse the valuation effects surrounding an M\&A announcement and then the distance to default. For this analysis, a number of variables are required, which we define and provide in Table 3.

The cumulative abnormal returns (CAR) of the target are calculated over a 3-day event window (Mitchell et al. 2001). This short time frame was chosen, as it should capture the entire valuation effects when the markets are efficient. Longer periods could cause biased results as more but different information may become available (Brown, Warner 1985). The calculations are performed as follows.

$$
C A R_{i}=\sum\left(R_{i, t}-E\left(R_{i, t}\right)\right)
$$

with,

$$
E\left(R_{i, t}\right)=\beta_{i t} * M R_{t}
$$

where $\mathrm{R}_{\mathrm{i}, \mathrm{t}}$ is the daily stock return for each company included in the sample for the 3-day period surrounding the $M \& A$ announcement, $E\left(R_{i, t}\right)$ is the expected return for the stock that is calculated in equation 2 , using the $\beta_{\text {it }}$ of the stock, which is a measure of the stock price sensitivity. $\mathrm{MR}_{\mathrm{t}}$ is the return of the market in which the stock is traded and $\mathrm{CAR}_{\mathrm{i}}$ is the cumulative abnormal return over the 3-day period.

Alternatively, we want to analyse whether some valuation effects occurred already before the official announcement of an M\&A and whether more M\&A relevant information become public later on. For this, we concentrate on a longer period surrounding the event. The buy-and-hold abnormal returns (BHAR) are calculated for the 21-day period surrounding the deal as below. 


$$
B H A R_{i}=\Pi\left(1+A R_{i, t}\right)-1
$$

with

$$
A R_{i, t}=R_{i, t}-E\left(R_{i, t}\right)
$$

$\mathrm{AR}_{\mathrm{i}, \mathrm{t}}$ is the abnormal return for any company $i$ at day $t$ in the time period examined and $\mathrm{BHAR}_{\mathrm{i}}$ is the buy-and-hold abnormal return for all specific company stocks in the sample. This is the return that an investor would have obtained above the market return when keeping the stock in a portfolio for a period $t$, in this case 20 days surrounding the M\&A announcement.

The default risk of the bidder and target firm was calculated from the 260 days preceding the announcement until the 260 days after the completion, similar to what previous studies did. For this, we employ Merton's distance to default (DD) model, which is an extension of the Black and Scholes (1973) option pricing model. We adopt the Merton DD model as described by Bharath and Shumway (2008). The formulas and data needed for our calculations are available in the Appendix.

For our hypotheses on the valuation effects, we create different subsamples from the overall sample. We also analyse the average CAR of the various samples, by running a two-sample t-test with equal variances. We test whether the hypothesized influences of the determinants are observable in the data. Afterwards we test all hypothesized relationships via cross-sectional regression analyses. The regression analyses include several control variables that are commonly used (cf. Maksimovna 2015), for example, the natural logarithm of the deal value, the stake that the acquiring company already owned in the target, the number of days the deal has taken for completion, and the profitability margin of both companies. Intuitive relationships between these control variables and the dependent variables are given in the results section.

Equation 5 depicts the regression used to analyse all hypothesized relationships.

$$
\text { BHAR }_{\text {target }}=\alpha-\beta_{1} S-\beta_{2} q \pm \beta_{3} D D_{\text {acq }} \pm \beta_{3} D D_{\text {tar }} \pm \beta_{i} \text { Controls }
$$

where $\mathrm{S}$ is a measure for the relative size of the acquiring company versus the target company, calculated by dividing the market capitalization of both companies at the announcement date. It is used to test the second hypothesis. Also, q is a measure for 
the acquirer versus target relative Tobin's q. It is used to test the third hypothesis. $\mathrm{DD}_{\mathrm{acq}}$ and $\mathrm{DD}_{\text {tar }}$ are the distance to default of the acquirer and target, respectively.

Table 3. Data needs for further analysis

\begin{tabular}{|c|c|c|c|}
\hline & Variable & Explanation & Database (source) \\
\hline $\begin{array}{l}\text { 40-day period stock } \\
\text { returns }\end{array}$ & $\mathrm{R}$ & $\begin{array}{l}\text { Surrounding the announcement, } \\
\text { for acquirer and target }\end{array}$ & $\begin{array}{l}\text { Thomson Reuters } \\
\text { DataStream }\end{array}$ \\
\hline Stock beta & B & For acquirer and target. & $\begin{array}{l}\text { Thomson Reuters } \\
\text { DataStream }\end{array}$ \\
\hline 40-day market return & MR & Surrounding the announcement & $\begin{array}{l}\text { Thomson Reuters } \\
\text { DataStream }\end{array}$ \\
\hline Market Capitalization & $\mathrm{V}$ & Daily on close & $\begin{array}{l}\text { Thomson Reuters } \\
\text { DataStream }\end{array}$ \\
\hline Total Liabilities & $\mathrm{K}$ & Quarterly & $\begin{array}{l}\text { Thomson Reuters } \\
\text { DataStream }\end{array}$ \\
\hline $\begin{array}{l}\text { Return on Assets } \\
\text { (ROA) }\end{array}$ & M & Quarterly & $\begin{array}{l}\text { Thomson Reuters } \\
\text { DataStream }\end{array}$ \\
\hline Risk-free rate & $\mathrm{R}$ & Daily on close & Investing.com \\
\hline Relative Tobin's q & Q & $\begin{array}{l}\text { Tobin's q acquirer / Tobin's q } \\
\text { target, both at announcement. }\end{array}$ & $\begin{array}{l}\text { Thomson Reuters } \\
\text { DataStream }\end{array}$ \\
\hline Relative Size & $\mathrm{S}$ & $\begin{array}{l}\text { Market cap acquirer / market cap } \\
\text { target, both at announcement. }\end{array}$ & $\begin{array}{l}\text { Thomson Reuters } \\
\text { DataStream }\end{array}$ \\
\hline $\begin{array}{l}\text { Payment method } \\
\text { (dummies) }\end{array}$ & $\mathrm{P}_{\mathrm{c}} \& \mathrm{P}_{\mathrm{s}}$ & $\begin{array}{l}\text { (Partially used) payment methods, } \\
\text { dummy variables are included for } \\
\text { cash and shares }\end{array}$ & Zephyr by BvD \\
\hline Country diversification & $\mathrm{CD}$ & $\begin{array}{l}\text { Dummy, } 1=\text { cross-country \& } 0= \\
\text { domestic }\end{array}$ & Zephyr by BvD \\
\hline $\begin{array}{l}\text { Continent } \\
\text { diversification }\end{array}$ & $\mathrm{CoD}$ & $\begin{array}{l}\text { Dummy, } 1=\text { cross-continent } \& 0= \\
\text { same continent }\end{array}$ & Zephyr by BvD \\
\hline Profit margin & $\pi_{\mathrm{i}}$ & $\begin{array}{l}\text { At announcement of acquirer and } \\
\text { target }\end{array}$ & $\begin{array}{l}\text { Thomson Reuters } \\
\text { DataStream }\end{array}$ \\
\hline $\begin{array}{l}\text { Days between } \\
\text { announcement and } \\
\text { completion }\end{array}$ & Days & $\begin{array}{l}\text { The amount of days between the } \\
\text { announcement and the completion } \\
\text { of the deal. }\end{array}$ & Zephyr by BvD \\
\hline Deal value & DV & $\begin{array}{l}\text { Natural logarithm of the deal value } \\
\text { in euros }\end{array}$ & Zephyr by BvD \\
\hline Initial Stake (\%) & IS & - & Zephyr by BvD \\
\hline Acquired Stake (\%) & AS & - & Zephyr by BvD \\
\hline \multicolumn{4}{|c|}{$\begin{array}{l}\text { Note 1: for all variables if there is no timespan specified, for the acquiring firm the following } \\
\text { periods will be collected: 260-day pre-announcement, between announcement and completion and } \\
\text { 260-day post-completion. For the target firm all variables are gathered for the periods preceding } \\
\text { the announcement and up until the completion. } \\
\text { Note 2: for the risk-free rate, the 30-year German government bond yield is used, as it is the most } \\
\text { widely used in practice and literature on European cases. } \\
\text { Note 3: Tobin's q is calculated by dividing the market value of equity and the book value of equity } \\
\text { (Kaldor, 1966). }\end{array}$} \\
\hline
\end{tabular}


For the default risk, we also analyse various subsamples based on the different dummy variables and other hypothesized relationships. These are examined in the same way as was discussed above and the results are available upon request. We run an overall regression, for which the hypothesized relations are depicted in the equation below.

$\Delta I A D D_{a c q}=\alpha-\beta_{1} D D_{\text {tar }}+\beta_{2} C D+\beta_{3} C o D-\beta_{4} P_{c}+\beta_{5} P_{s}-\beta_{6} S \pm \beta_{i}$ Control

$\triangle \mathrm{IADD}_{\text {acq }}$ is the change in industry-adjusted distance to default of the acquiring company between before the announcement and after the completion of the deal. It is industry-adjusted by taking the average change in distance to default of each industry and calculating the difference from that for each acquiring firm. This is done to account for inter-industry and time effects. $\mathrm{DD}_{\mathrm{tar}}$ is the distance to default of the target company. CD is a dummy variable for country diversification, with a value of 1 when the target is from a different country than the acquirer and $\mathrm{CoD}$ is a dummy variable for continent diversification, with a value of 1 when the target is from a different continent than the acquirer. Both variables are used to test the sixth hypothesis. $\mathrm{P}_{\mathrm{c}}$ and $\mathrm{P}_{\mathrm{s}}$ are dummy variables used to test for the seventh hypothesis. They are variables that are assigned a value of 1 when cash or shares, respectively, are at least partially used by the acquirer to pay for the target company.

\section{Data and descriptive statistics}

In this section, we present the sample and explain the restrictions imposed on it. We also provide additional insights into the data by portraying the descriptive statistics. Furthermore, we discuss some of the subsamples to study size and Tobin's q effects in more depth. The sample is gathered by hand and comprises of deals that were completed between the $1^{\text {st }}$ of October 1998 and the $5^{\text {th }}$ of March 2018. The end date is chosen to ensure that there are at least 260 trading days subsequent to the completion of the last deal and the time of the analysis. This is also important for the analysis of the distance to default in the next section. 
There are multiple restrictions for constructing the sample. First, banks and utilities are excluded (Furfine, Rosen 2011) as well as all deals with a value below $€ 1$ million (Moeller et al. 2005) to include only deals that have a significant economic impact (Maksimovna 2015). Only M\&A's are included in the sample, which means that LBO's and private equity deals are excluded. The pre-merger ownership must be below $50 \%$ and the post-merger ownership of the target by the bidder must exceeds $50 \%$ (Furfine, Rosen 2011). Because of our focus on Europe, a requirement is that an acquiring firm's home country has to belong to the enlarged European Union of 28 countries. Our requirements lead to a sample size of 1,050 deals, which details have been obtained via Zephyr by Bureau van Dijk (BvD). The data, however, had to be thoroughly cleaned by hand because of missing data on key variables. This resulted in a final sample size of $531 \mathrm{M} \& A s$. The cleaning procedure is available upon request. The distance to default, profit margin, and the CAR are winsorized on the $1 \%$ and $99 \%$ level, to account for extreme values and outliers in these variables. Our robustness test suggests that this practice does not significantly influence the results.

In Table 4, we provide the geographic locations of all firms. There are many countries that have a rather low number of acquiring firms over the sample period. As an unpublished robustness test available from the authors upon request, the deals were excluded in which the acquiring firm was from a small deal country with fewer than 10 deals over the sample period. The results do not change significantly when leaving these deals out of the sample. The spread of country and continent diversification deals can also be found in Table 4 .

In Table 5, we present the number of deals per year. From this table no real pattern can be observed. There is a higher number of deals in the years prior to the 2008/2009 Global Financial Crisis, which might be due to the positive growth expectations during these years. Furthermore, it needs to be noted that the sample is unevenly spread over the countries. In an unpublished test that is available upon request, we find indications that this does not have a material impact on our results. 
Table 4. Distribution of deals

\begin{tabular}{|c|c|c|c|c|c|}
\hline & $\begin{array}{c}\text { No. of } \\
\text { acquirers }\end{array}$ & $\begin{array}{l}\text { No. of } \\
\text { targets }\end{array}$ & & $\begin{array}{c}\text { No. of } \\
\text { acquirors }\end{array}$ & $\begin{array}{l}\text { No. of } \\
\text { targets }\end{array}$ \\
\hline $\begin{array}{l}\text { Home } \\
\text { country }\end{array}$ & & & Industry & & \\
\hline Austria & 3 & 5 & $\begin{array}{l}\text { Chemicals, rubber, plastics, } \\
\text { non-metallics }\end{array}$ & 68 & 66 \\
\hline Belgium & 14 & 9 & Construction & 32 & 32 \\
\hline Denmark & 9 & 5 & Education, Health & 3 & 3 \\
\hline Finland & 16 & 13 & Food, Beverages, tobacco & 31 & 31 \\
\hline France & 88 & 63 & Hotels \& Restaurants & 18 & 18 \\
\hline Germany & 50 & 38 & $\begin{array}{l}\text { Machinery \& Equipment, } \\
\text { furniture, recycling }\end{array}$ & 82 & 81 \\
\hline Great-Britain & 170 & 127 & Metals \& metal products & 28 & 28 \\
\hline Greece & 11 & 16 & Post, Telecommunication & 43 & 43 \\
\hline Ireland & 21 & 5 & $\begin{array}{l}\text { Primary sector (agriculture, } \\
\text { mining, etc.) }\end{array}$ & 14 & 14 \\
\hline Italy & 23 & 10 & Publishing, print & 9 & 9 \\
\hline Luxembourg & 8 & 2 & Textiles, apparel, leather & 5 & 5 \\
\hline Malta & 1 & 1 & Transport & 7 & 7 \\
\hline Netherlands & 38 & 15 & Wholesale $\&$ retail trade & 37 & 37 \\
\hline Poland & 12 & 15 & Wood, cork, paper & 7 & 7 \\
\hline Portugal & 2 & 5 & Other services & 147 & 150 \\
\hline Spain & 26 & 16 & Total & 531 & 531 \\
\hline Sweden & 39 & 19 & & & \\
\hline Other-Europe & 0 & 32 & $\begin{array}{l}\text { Geographical } \\
\text { diversification }\end{array}$ & & \\
\hline $\begin{array}{l}\text { North- } \\
\text { America }\end{array}$ & 0 & 95 & Domestic & 249 & \\
\hline SCA & 0 & 14 & Cross-border & 282 & \\
\hline Asia & 0 & 12 & Total & 531 & \\
\hline Africa & 0 & 9 & & & \\
\hline Oceania & 0 & 4 & Europe & 396 & \\
\hline Other & 0 & 1 & Cross-continent & 135 & \\
\hline Total & 531 & 531 & Total & 531 & \\
\hline
\end{tabular}


DO MERGERS AND ACQUISITIONS INCREASE DEFAULT RISK?

Table 5. Number of deals per year

\begin{tabular}{|c|c|c|c|}
\hline Year of completion & $\begin{array}{c}\text { Number of } \\
\text { Observations }\end{array}$ & Year of completion & $\begin{array}{c}\text { Number of } \\
\text { Observations }\end{array}$ \\
\hline 1998 & 2 & 2009 & 13 \\
\hline 1999 & 8 & 2010 & 23 \\
\hline 2000 & 39 & 2011 & 23 \\
\hline 2001 & 24 & 2012 & 24 \\
\hline 2002 & 21 & 2013 & 24 \\
\hline 2003 & 28 & 2014 & 25 \\
\hline 2004 & 35 & 2015 & 31 \\
\hline 2005 & 30 & 2016 & 22 \\
\hline 2006 & 55 & 2017 & 19 \\
\hline 2007 & 50 & 2018 & 3 \\
\hline 2008 & 32 & Total & $\mathbf{5 3 1}$ \\
\hline
\end{tabular}

Table 6. Variables descriptions

\begin{tabular}{|c|l|c|r|r|r|r|}
\hline \multicolumn{1}{|c|}{ Variables } & n & Mean & \multicolumn{1}{c|}{ Std. Dev. } & Min & Max \\
\hline 1 & BHAR(-10;+10) bidder & 531 & 0.01 & 0.10 & -0.37 & 0.46 \\
\hline 2 & BHAR(-10;+10) target & 531 & 0.15 & 0.28 & -1.00 & 3.54 \\
\hline 3 & CAR(-1;+1) bidder & 531 & 0.00 & 0.04 & -0.12 & 0.17 \\
\hline 4 & CAR(-1;+1) target & 531 & 0.12 & 0.18 & -0.10 & 0.97 \\
\hline 5 & Adjusted DD change & 531 & 0.00 & 17.57 & -131.95 & 66.11 \\
\hline 6 & DD(-130; -5) acquirer & 531 & 29.72 & 28.09 & -43.25 & 116.86 \\
\hline 7 & DD(-130; -5;) target & 531 & 29.36 & 45.37 & -123.35 & 206.03 \\
\hline 8 & Initial stake & 531 & 0.22 & 0.32 & 0.00 & 1.00 \\
\hline 9 & Acquired stake & 531 & 0.72 & 0.36 & 0.00 & 1.00 \\
\hline 10 & Days in between & 531 & 107.21 & 97.12 & 0.00 & 660.00 \\
\hline 11 & Relative Size & 531 & 34.39 & 185.86 & 0.14 & 3765.38 \\
\hline 12 & Log deal value & 531 & 19.56 & 2.07 & 16.21 & 24.92 \\
\hline 13 & Relative Tobin's q & 531 & 1.94 & 9.22 & 0.03 & 205.46 \\
\hline 14 & Profit margin acquirer & 531 & 0.11 & 0.18 & -0.89 & 0.71 \\
\hline 15 & Profit margin target & 531 & -0.03 & 0.90 & -7.15 & 0.78 \\
\hline 16 & Cross country & 531 & 0.53 & 0.50 & 0 & 1 \\
\hline 17 & Cross continent & 531 & 0.25 & 0.44 & 0 & 1 \\
\hline 18 & Payment cash & 486 & 0.79 & 0.41 & 0 & 1 \\
\hline 19 & Payment equity & 486 & 0.45 & 0.50 & 0 & 1 \\
\hline 20 & Liability-equity ratio bidder & 531 & 1.43 & 1.93 & 0.01 & 20.44 \\
\hline 21 & Liability-equity ratio bidder & 531 & 2.58 & 27.49 & 0.00 & 538.10 \\
\hline
\end{tabular}

Note: if no time period is specified the data refer to the date of announcement of the deal. 
Wolfgang BESSLER, Hidde STEENBEEK, Wim WESTERMAN

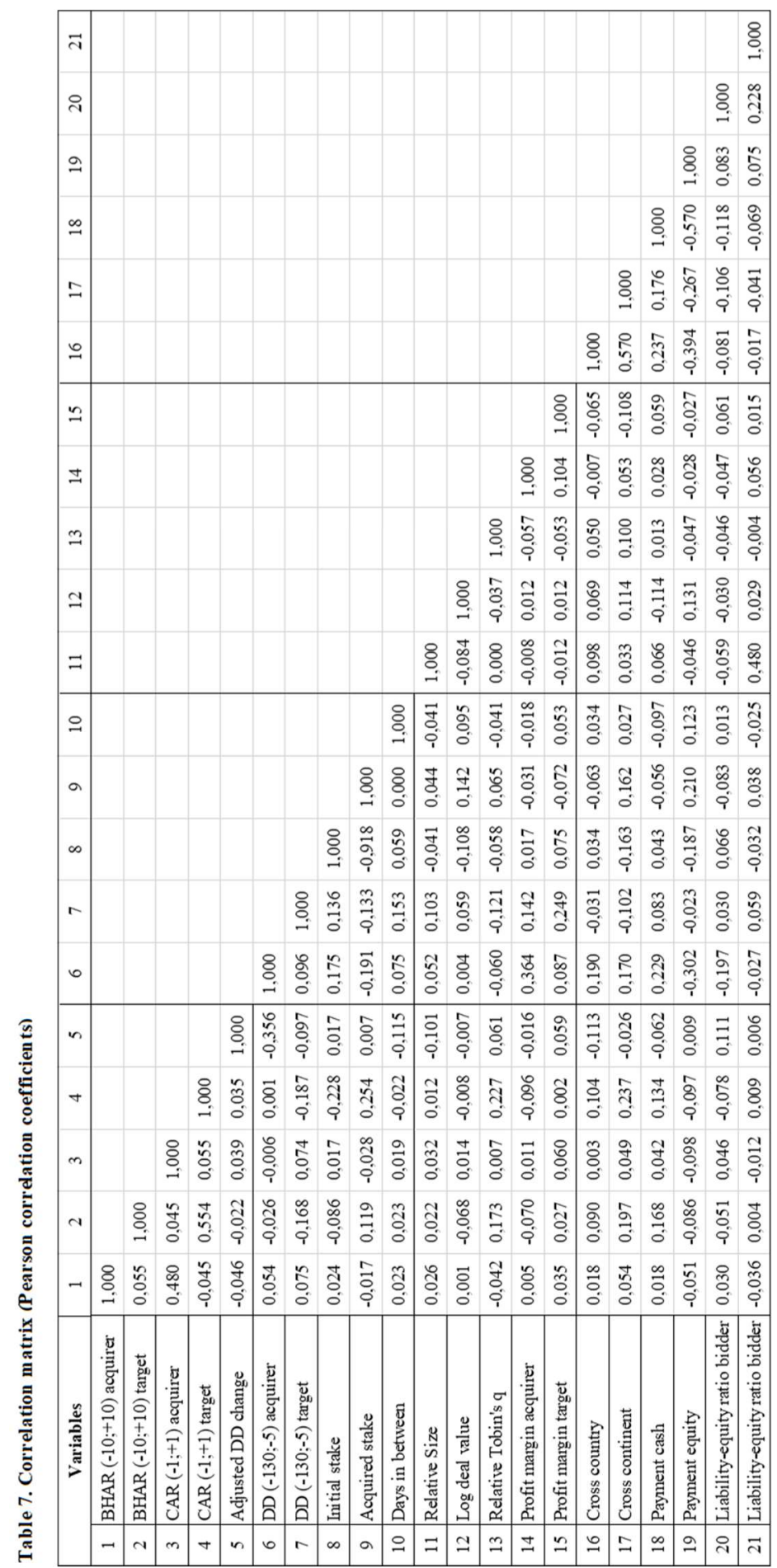


Table 6 provides the descriptive statistics of our study. In Table 7 we present the correlation matrix. Overall, most Pearson correlation coefficients are close to zero. The correlation between the distance to default of the acquirer and the industryadjusted change in distance to default is $\rho=-0.356$. When the first variable rises by $1 \%$, the second one decreases by $0.356 \%$. Acquiring firms with higher distance to default before the deal experience a decrease in their distance to default during the merger process. The correlation between initial stake and acquired stake is nearly perfectly negative $(\rho=-0.918$ ), but only the first is chosen as a control variable. The correlation between share payments and cross-country deals is also remarkable ( $\rho=-$ 0.394). Cross-country deals are less often paid with shares. Acquirers are less prone to exchange shares with a foreign target in an M\&A deal, or more likely, the shareholders of the foreign targets are much less interested in receiving shares of the bidder as the monitoring and transaction cost for these shares could be relatively high later on.

Figure 1. The buy-and-hold abnormal return around the announcement

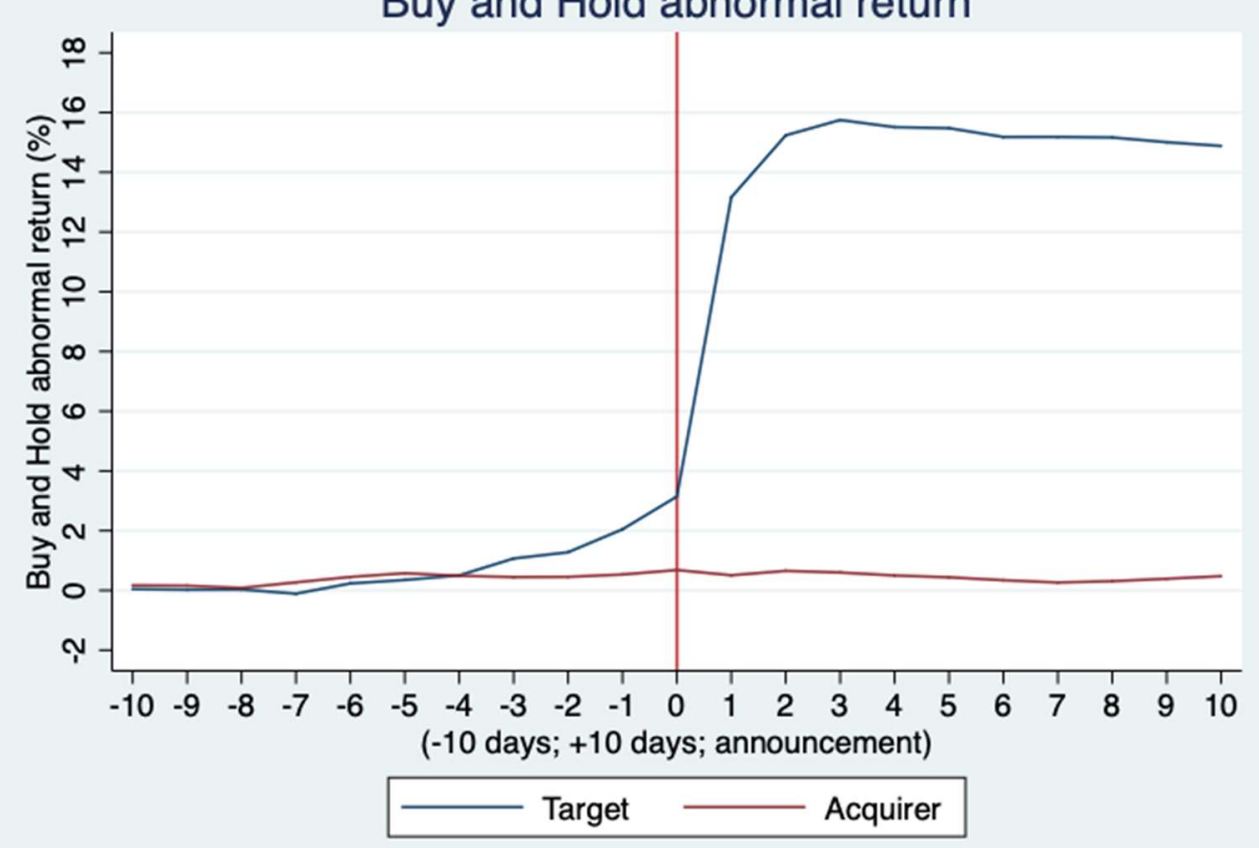


Figure 1 depicts the development of the average buy-and-hold abnormal returns (BHAR) for the 21-day period surrounding the announcement for the entire sample. There is a run-up period prior to the announcement in the abnormal returns of the target of around 6 days. After the third day, the target underperforms the market. These observations are confirmed by unpublished but available on request $t$-tests for various CAR intervals (cf. Tang, Xu 2016). A run-up period indicates that markets are most likely not perfectly efficient, since apparently some investors have access to privileged information and trade on these beforehand. Underperformance afterwards is not standard and could be caused by sampling of unsuccessful deals (Schwert 1996), which is not the case here. Another reason might be that an M\&A deal is overpriced surrounding the announcement. This would lead to the market compensating this error later on.

Table 8. Distribution of firm default risk, measured by distance to default

\begin{tabular}{|c|c|c|c|c|c|}
\hline $\begin{array}{l}\text { Distance to } \\
\text { default }\end{array}$ & $\begin{array}{l}\text { Probability of } \\
\text { default (PD) }\end{array}$ & $\begin{array}{l}\text { S\&P rating } \\
\text { equivalent }\end{array}$ & & $\mathbf{n}_{\text {acquirers }}$ & $\mathbf{n}_{\text {targets }}$ \\
\hline $17.598>$ & $<0.0002 \%$ & AAA & $\begin{array}{l}\text { Investment } \\
\text { Grade }\end{array}$ & 357 & 352 \\
\hline $\begin{array}{l}17.598-> \\
8.696\end{array}$ & $\begin{array}{l}0.0002 \%-> \\
0.0016 \%\end{array}$ & $\begin{array}{l}\mathrm{AA} \mathrm{->} \\
\mathrm{BBB}+\end{array}$ & $\begin{array}{l}\text { Investment } \\
\text { grade }\end{array}$ & 78 & 54 \\
\hline $8.696->1.316$ & $\begin{array}{l}0.0016 \%-> \\
13.99 \%\end{array}$ & BBB -> B- & High Yield & 32 & 29 \\
\hline \multirow[t]{2}{*}{$<1.316$} & $14 \%>$ & $<\mathrm{C}$ & High Yield & 64 & 96 \\
\hline & & & Total & 531 & 531 \\
\hline
\end{tabular}

In Table 8, we present the distribution of the distance to default of the acquirer and the target. For the preliminary analysis, the subsample on financial performance is based on whether the corporate bond of the acquirer or target is investment grade (IG) or high yield (HY). The rating is determined based on the distance to default as calculated via the Merton (1974) model. In the overall regression analysis, the actual distance to default is used. Some sample firms are rated as high as AAA, most of them are rated lower and there is a number of firms that are almost in distress (below Crated). They will be analysed as well. 
Table 9. Distribution of leverage ratio

\begin{tabular}{|l|c|c|c|c|c|c|c|c|c|c|}
\hline & \multicolumn{5}{|c|}{ Acquirer } & \multicolumn{5}{c|}{ Target } \\
\hline & All & & IG & & HY & All & & IG & HY \\
\hline Liability to equity ratio & & & & & & & & & \\
\hline Mean & 1.385 & & 1.222 & & 2.125 & 0.926 & 0.803 & 1.323 \\
\hline $\mathrm{N}$ & 531 & 435 & & 96 & 531 & 406 & 125 \\
\hline Note: All of the portrayed variables are winsorized at the 1st and 99th percentile. \\
\hline
\end{tabular}

Results in Table 9 indicate that the high-yield firms have, on average, a higher leverage level, measured via a liabilities-to-equity ratio. This is as expected, since a higher leverage level means a higher face value of debt and thus a smaller distance to default and higher default risk. In table 10, we present the descriptive statistics on the different payment methods used in the analysis. These dummy variables refer to a payment method when it is at least partially used.

Table 10. Distribution of partially used payment methods

\begin{tabular}{|l|c|c|c|}
\hline Payment method & (Partially) used & Not used & Total \\
\hline Cash & 385 & 101 & 486 \\
\hline Shares & 269 & 217 & 486 \\
\hline
\end{tabular}

\section{Empirical results}

In this section, we present the results of our empirical analyses and evaluate the validity of our hypotheses. The first part focusses on the data set by examining the valuation effects for the shareholders of the target firm. Afterwards, we concentrate on the main objective of this article by analysing the change in default risk before and subsequent to the merger. 


\section{$M \& A s$ and valuation effects}

The results in Table 11 reveal that the cumulative abnormal return of the acquirer is on average $0.094 \%$ in the 3-day window around the M\&A announcement. A twosided t-test, however, indicates that this difference is not significant $(\mathrm{p}=0.615)$ different from zero, suggesting that there is no immediate benefit for the acquirer's shareholders. In contrast, the results for the target firm's shareholders do reveal significantly $(\mathrm{p}=0.000)$ positive cumulative abnormal returns $(\mathrm{CAR}=11.716 \%)$ around the announcement day, which supports our first hypothesis. This means that the target's shareholders of our sample firms fully demand and obtain the expected synergy gains as a premium for agreeing to the acquisition or for tendering their shares. Bidder shareholder could only benefit in the future from the unexpected and not yet valued synergies. This result is consistent with the ones previously documented in the literature (Bessler, Schneck 2015, 2016).

Table 11. Cumulative abnormal returns for the full sample

\begin{tabular}{|l|c|c|}
\hline & Acquirer & Target \\
\hline Average of $\mathrm{CAR}_{(-1 ;+1 ; \text { announcement })}(\%)$ & 0.094 & 11.716 \\
\hline $\mathrm{t}$-statistic & 0.504 & 14.885 \\
\hline $\mathrm{p}$-value & 0.615 & 0.000 \\
\hline $\mathrm{N}$ & 531 & 531 \\
\hline $\begin{array}{l}\text { Note: } \text { two-sided independent } t \text {-test conducted to test whether on average the CAR is } \\
\text { significantly different from 0, which is also the reported } \text {-statistic. }\end{array}$ \\
\hline
\end{tabular}

In Table 12 we report the findings for our second hypothesis, expecting that the relative size and the valuation effects for the target are positively related. When relative size is higher than the median, the average CAR of the target is more than twice as large $(\overline{\mathrm{CAR}}=15.70 \%)$ than when the relative size is below the median of 4.29 $(\overline{\mathrm{CAR}}=7.75 \%)$. The difference is significantly different from zero $(\mathrm{p}=0.000)$, suggesting that target shareholders experience larger positive valuation effects when a relatively larger acquirer buys a smaller target. This initial evidence for the size effect as described by Moeller et al. (2004) is hardly surprising. Even when a larger firm only pays a marginally higher sum, this results in significantly higher target returns. Offering a relatively higher price for smaller targets also prevents other 
bidders to enter into a competition for the target, which otherwise would make the deal much more expensive for the bidder (Bessler et al. 2015).

Table 12. Cumulative abnormal returns for the relative size subsamples

\begin{tabular}{|c|c|}
\hline Relative size $\geq$ median (4.29) & Target \\
\hline Average of $\mathrm{CAR}_{(-1 ;+1 ; \text { announcement })}(\%)$ & 15.697 \\
\hline t-statistic & 11,703 \\
\hline p-value & 0.000 \\
\hline $\mathrm{N}$ & 265 \\
\hline \multicolumn{2}{|l|}{ Relative size < median (4.29) } \\
\hline Average of $\mathrm{CAR}_{(-1 ;+1 ; \text { announcement })}(\%)$ & 7.750 \\
\hline t-statistic & 10.273 \\
\hline p-value & 0.000 \\
\hline $\mathrm{N}$ & 266 \\
\hline \multicolumn{2}{|l|}{ Difference in means } \\
\hline t-statistics & -5.169 \\
\hline p-value & 0.000 \\
\hline $\mathrm{N}$ & 531 \\
\hline
\end{tabular}

However, the significant relationship could be influenced by other factors that correlate with relative size. Therefore, we test this relationship in a general regression model for which we present the findings in Table 14. The results support the positive relationship between the relative size and the 21-day buy-and-hold-abnormal returns ( $\beta=0.0002 ; p=0.016$ ), thus providing further evidence for our second hypothesis. In contrast, this result might indicate that when the target is of similar size or relatively larger than the bidder, the integration into the acquiring firm might require more complicated integration efforts (Antoniou et al. 2008) creating less value.

The exploratory results on the third hypothesis are presented in Table 13. They suggest that there is a positive relationship between relative Tobin's $\mathrm{q}$ and the valuation effects of the target. According to Wang and Xie (2008), target firms would usually benefit from a merger with or acquisition by a relatively 'better' managed firm. This expectation is also supported by our initial test, which suggests that when 
the relative Tobin's $q$ is larger than the median (1.04) the average CAR is significantly higher $(\overline{\mathrm{CAR}}=14.26 \% ; \overline{\mathrm{CAR}}=9.16 \%) ; \mathrm{p}=0.001)$. This evidence is also supported by the overall regression results in Table $13(\beta=0.00406 ; p=0.000)$. This result implies that when the Tobin's q of the acquiring firm increases by one relative to the Tobin's $\mathrm{q}$ of the target, the 21-day buy-and-hold-abnormal return increases by $0.41 \%$. This suggests that indeed the target shareholders benefit more from merging with or being acquired by a more efficiently managed acquirer. When managed under the direction of the 'superior' acquirer's management team, the merged firm can behave more efficiently and create higher cash flows than before.

Table 13. Cumulative abnormal returns for the relative Tobin's q subsamples

\begin{tabular}{|c|c|}
\hline Relative Tobin's $q \geq$ median (1.04) & Target \\
\hline Average of CAR $\mathrm{CA}_{(-1 ;+1 ; \text { announcement })}(\%)$ & 14.264 \\
\hline t-statistic & 11.327 \\
\hline p-value & 0.000 \\
\hline $\mathrm{N}$ & 266 \\
\hline \multicolumn{2}{|l|}{ Relative Tobin's q < median (1.04) } \\
\hline Average of $\mathrm{CAR}_{(-1 ;+1 ; \text { announcement }}(\%)$ & 9.159 \\
\hline t-statistic & 9.963 \\
\hline p-value & 0.000 \\
\hline \multicolumn{2}{|l|}{$\mathrm{N}$} \\
\hline \multicolumn{2}{|l|}{ Difference in means } \\
\hline t-statistics & -3.272 \\
\hline $\mathrm{p}$-value & 0.001 \\
\hline $\mathrm{N}$ & 531 \\
\hline
\end{tabular}

Next to the evidence that supports the first three hypotheses on valuation effects, Table 14 highlights some other interesting and significant results. There is a positive and significant relationship between cash as a method of payment and target valuation effects $(\beta=0.128 ; p=0.005)$. When cash is at least partially used for payment, the buyand-hold abnormal return are, on average, higher. One explanation for this observation is the positive signalling effect resulting from paying with cash (Yook 
2003). In this case, the acquiring firm unintentionally signals that the target firm is undervalued, at least from their perspective, or that at the current offering price the deal has a positive net present value and the bidder does not want to share the gains with the target shareholders. The coefficient for the cross-continent dummy is also significant and positive $(\beta=0.118 ; \mathrm{p}=0.025)$. This implies that when the target is nonEuropean, and the acquirer is European, the valuation effect of the target is larger, which also means that the premium that needs to be or is paid in foreign acquisitions is higher. One possible explanation is that in other continents the target shareholders demand a higher premium for being acquired by a European firm. It is also possible that the synergistic gains are larger, justifying the payment of a higher premium.

Table 14. Results of OLS regressions on the Buy and Hold abnormal return

\begin{tabular}{|l|c|c|c|c|}
\hline Variables & Hypotheses & $\mathbf{( 1 )}$ & $\mathbf{( 2 )}$ & $\mathbf{( 3 )}$ \\
\hline Profit margin of Acquirer & + & $-0.13244^{* *}$ & $-0.11915^{* *}$ & -0.07417 \\
\hline & & $(0.05460)$ & $(0.05403)$ & $(0.05875)$ \\
\hline Profit margin of Target & + & 0.01567 & 0.01706 & $0.02612^{* *}$ \\
\hline & & $(0.01126)$ & $(0.01100)$ & $(0.01144)$ \\
\hline & & & & \\
\hline Payment dummy cash & + & $0.11074^{* * *}$ & $0.11363^{* * *}$ & $0.12764^{* * *}$ \\
\hline Payment dummy shares & & $(0.04268)$ & $(0.04278)$ & $(0.04528)$ \\
\hline & - & 0.02193 & 0.02553 & 0.02847 \\
\hline Cross-country & & $(0.05825)$ & $(0.05830)$ & $(0.05542)$ \\
\hline & + & -0.02485 & -0.02407 & -0.02307 \\
\hline Cross-continent & & $(0.02396)$ & $(0.02403)$ & $(0.02395)$ \\
\hline & + & $0.13695^{* *}$ & $0.12755^{* *}$ & $0.11745^{* *}$ \\
\hline $\begin{array}{l}\text { Days between announcement and } \\
\text { completion }\end{array}$ & & $(0.05308)$ & $(0.05290)$ & $(0.05212)$ \\
\hline & & 0.00011 & 0.00012 & $0.00019 *$ \\
\hline Log of deal value & & $(0.00010)$ & $(0.00010)$ & $(0.00011)$ \\
\hline & $?$ & $-0.01182^{*}$ & $-0.01082^{*}$ & -0.00783 \\
\hline Initial stake (\%) & & $(0.00650)$ & $(0.00650)$ & $(0.00606)$ \\
\hline & + & -0.05648 & -0.04987 & -0.03125 \\
\hline Relative Size & & $(0.07063)$ & $(0.07037)$ & $(0.07422)$ \\
\hline & + & & 0.00001 & $0.00020^{* *}$ \\
\hline
\end{tabular}


Table 14. Cont. ...

\begin{tabular}{|l|c|c|c|c|}
\hline Variables & Hypotheses & (1) & (2) & (3) \\
\hline Relative Tobin's q & + & & $0.00437^{* * *}$ & $0.00406^{* * *}$ \\
\hline & & & $(0.00102)$ & $(0.00091)$ \\
\hline $\begin{array}{l}\text { DD[-130; -5; announcement] } \\
\text { acquirer }\end{array}$ & $?$ & & & -0.00034 \\
\hline & & & & $(0.00040)$ \\
\hline DD[-130; -5; announcement] target & $?$ & & & $-0.00086^{* * *}$ \\
\hline & & & & $(0.00027)$ \\
\hline Constant & & $0.27943^{* * *}$ & $0.24454^{* *}$ & $0.18836^{*}$ \\
\hline & & $(0.10192)$ & $(0.09966)$ & $(0.09705)$ \\
\hline & & & 486 \\
\hline Observations & & 486 & 486 & 0.10300 \\
\hline Adjusted R-squared & & 0.06355 & 0.08192 & 7.52 \\
\hline F-statistic & 6.94 & 7.41 & \\
\hline \multicolumn{4}{|l|}{ Robust standard errors in parentheses } \\
\hline $\begin{array}{l}\text { Note 1: The dependent variable is the BHAR, which is the buy-and-hold abnormal return of the 20-day } \\
\text { period [-10; }+10] \text { surrounding the announcement date. }\end{array}$ \\
$\begin{array}{l}\text { Note 2: DD is the distance to default of the respective firm (a higher value on this variable refers to a } \\
\text { better performing firm). }\end{array}$ \\
$\begin{array}{l}\text { Note 3: All variables are either the mean from the period surrounding the announcement date, which is } \\
\text { shown by the number of business days in the brackets, or at the announcement date. }\end{array}$ \\
\hline
\end{tabular}

The last result to be discussed is the negative and significant relationship between the distance to default of the target and its buy-and-hold-abnormal return $(\beta=-0.00086$; $\mathrm{p}=0.001)$. A riskier target in an M\&A deal will generate higher abnormal returns (BHAR) for its shareholders. This could be resulting from a favourable market reaction because the acquirer is in a way rescuing the target from defaulting, but at a very lucrative price at it assumes the default risk. However, the target's default risk may not cause any problems when integrated into the bidder's operations. Another example is that the risk and cash flows of bidder and target are negatively correlated, offering some diversification benefits. Along this thinking it is also possible that acquiring firms value target firms with a lower distance to default relatively higher as the potential gains may exceed the ones from normal deals, and they usually are able to bear the risk that might be transferred through the M\&A transaction. Figuring out the reasoning behind this and how an acquisition or merger affects the default risk over the deal process are the main objectives of this study. 


\section{$M \& A s$ and default risk}

The cumulative distance to default in the European sample is not normally distributed as can be observed in Figure 2a and 2b. A Shapiro-Wilk test for normality confirms that the distance to default of both the acquirer and the target is non-normal. To obtain the probability of default a t-distribution with 3 degrees of freedom is used, following the previous literature (Furfine, Rosen 2011).

Our conclusion from this analysis is that the average change in distance to default is negative and significant ( $\triangle \mathrm{DD}=-2,668 ; \mathrm{p}=0.001$ ) and the distance to default has a negative relationship with default risk (see also figure 3 ). The results provided in Table 15 indicate that, on average, mergers and acquisitions increase the default risk of the bidder or the merged firm. Thus, we find support for our fourth hypothesis. The result might be partially due to other effects such an increase in leverage when additional debt is issued to finance the deal, or when the target has a high leverage before the deal and the bidder assumes the debt and is increasing its own leverage. This is often the case in a merger or acquisition (Ghosh, Jain 2000).

Figure 2a. Distance to default of acquiring firms prior to the announcement

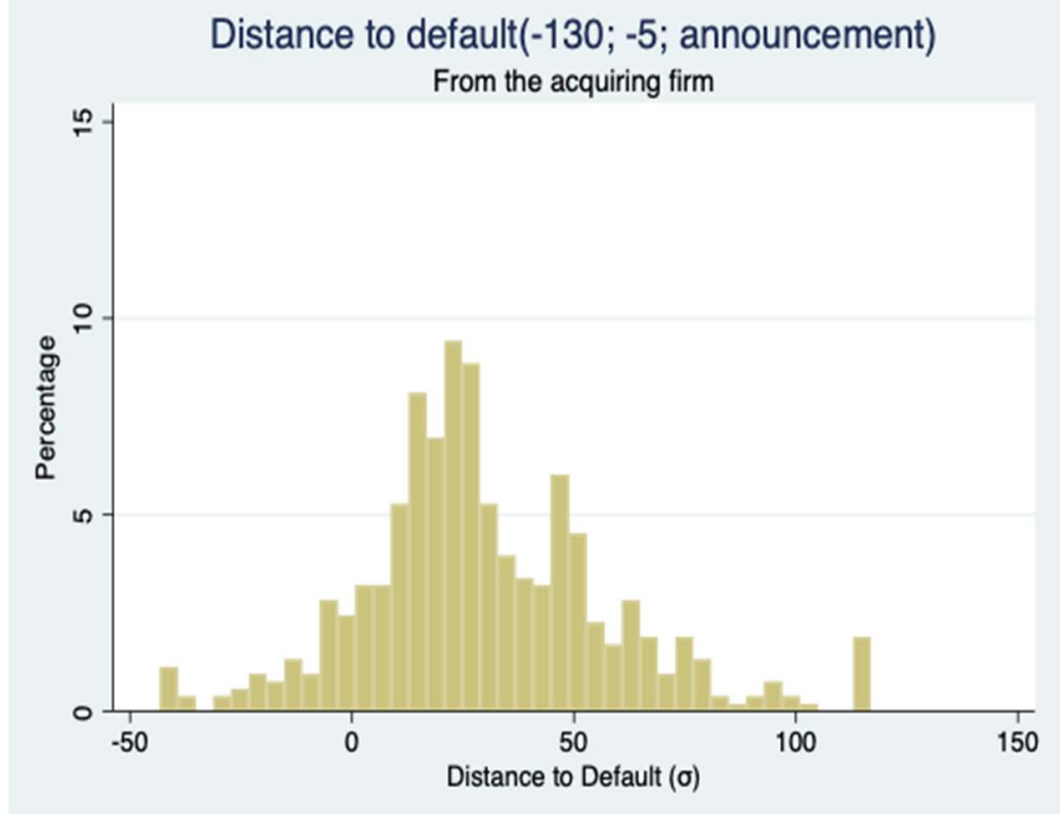

Note: This graph was constructed after winsorizing at the 1st and 99th percentile. 
Figure 2b. Distance to default of target firms prior to the announcement

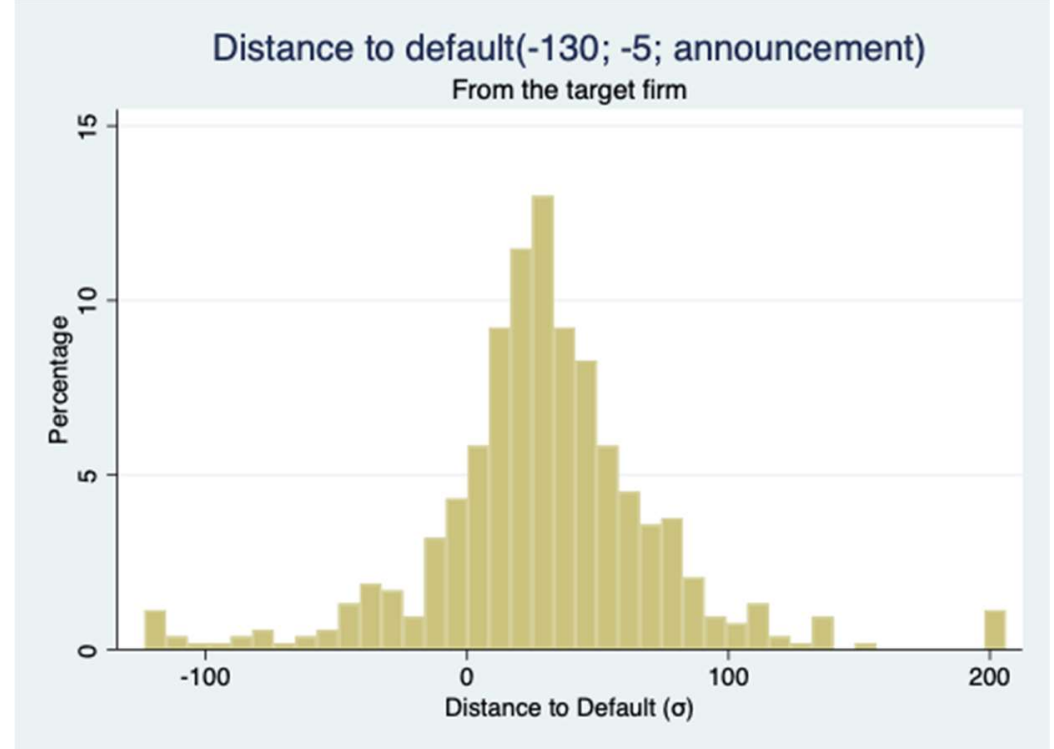

Note: This graph was constructed after winsorizing at the 1st and 99th percentile.

Figure 3. Average acquiring firm distance to default, over the deal process

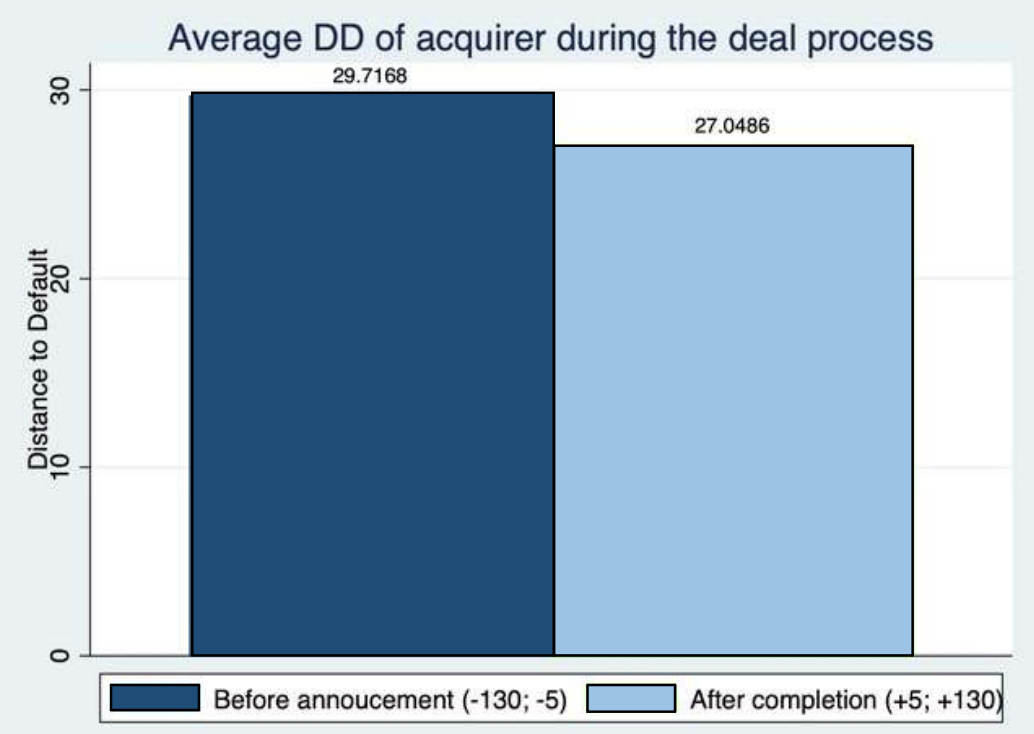

Note 1: This graph was constructed after winsorizing at the 1st and 99th percentile.

Note 2: For the construction of this graph, the average of two periods were taken per firm, the 125 days leading up to 5 days before the announcement and the 125-day period 5 days after the completion of the deal. From these two averages, the average across the sample was calculated. 
DO MERGERS AND ACQUISITIONS INCREASE DEFAULT RISK?

Table 15. Results of the change in Merton distance to default

\begin{tabular}{|l|c|}
\hline & Acquirer \\
\hline Average change in distance to default & -2.668 \\
\hline t-statistic & -3.443 \\
\hline $\mathrm{P}$ & 0.001 \\
\hline $\begin{array}{l}\text { Note: } \text { two-sided independent t-test conducted to test whether on average the change in } \\
\text { distance to default is significantly different from } 0 .\end{array}$ \\
\hline
\end{tabular}

Table 16. OLS regression results for the industry-adjusted change in distance to default

\begin{tabular}{|c|c|c|c|}
\hline Variables & Hypotheses & (1) & (2) \\
\hline \multirow[t]{2}{*}{ BHAR $[-10 ;+10 ;$ announcement $]$ acquirer } & $?$ & -7.120 & -4.599 \\
\hline & & $(7.925)$ & $(8.420)$ \\
\hline \multirow[t]{2}{*}{ BHAR $[-10 ;+10 ;$ announcement $]$ target } & $?$ & -1.208 & -3.463 \\
\hline & & $(4.731)$ & $(4.830)$ \\
\hline \multirow[t]{2}{*}{ Profit margin of Acquirer } & + & -2.349 & $12.877 * *$ \\
\hline & & $(5.311)$ & $(5.872)$ \\
\hline \multirow[t]{2}{*}{ Profit margin of Target } & + & 1.325 & $2.098 * *$ \\
\hline & & $(1.052)$ & $(0.928)$ \\
\hline \multirow[t]{2}{*}{ Days between announcement and completion } & $?$ & $-0.021 * * *$ & -0.011 \\
\hline & & $(0.008)$ & $(0.007)$ \\
\hline \multirow[t]{2}{*}{ Log of deal value } & $?$ & 0.023 & 0.158 \\
\hline & & $(0.391)$ & $(0.387)$ \\
\hline \multirow[t]{2}{*}{ Initial stake (\%) } & + & 1.120 & $5.486^{*}$ \\
\hline & & $(2.491)$ & $(2.968)$ \\
\hline \multirow[t]{2}{*}{ Payment dummy cash } & - & & -1.172 \\
\hline & & & $(2.313)$ \\
\hline \multirow[t]{2}{*}{ Payment dummy shares } & + & & $-5.104 * *$ \\
\hline & & & $(2.004)$ \\
\hline \multirow[t]{2}{*}{ Cross-country } & + & & $-4.667 * *$ \\
\hline & & & $(1.855)$ \\
\hline \multirow[t]{2}{*}{ Cross-continent } & + & & $4.543 *$ \\
\hline & & & $(2.562)$ \\
\hline Relative Size & - & & $-0.005^{*}$ \\
\hline
\end{tabular}


Table 16. Cont. ...

\begin{tabular}{|c|c|c|c|}
\hline Variables & Hypotheses & (1) & (2) \\
\hline & & & $(0.003)$ \\
\hline \multirow[t]{2}{*}{ Relative Tobin's q } & $?$ & & 0.071 \\
\hline & & & $(0.068)$ \\
\hline \multirow[t]{2}{*}{ DD[-130; -5; announcement] acquirer } & $?$ & & $-0.281 * * *$ \\
\hline & & & $(0.050)$ \\
\hline \multirow[t]{2}{*}{ DD[-130; -5; announcement] target } & - & & $-0.039 *$ \\
\hline & & & $(0.024)$ \\
\hline \multirow[t]{2}{*}{ Constant } & & 2.100 & 9.859 \\
\hline & & $(7.465)$ & $(8.277)$ \\
\hline Observations & & 531 & 486 \\
\hline Adjusted R-squared & & 0.007 & 0.176 \\
\hline F-statistic & & 1.52 & 5.26 \\
\hline \multicolumn{4}{|c|}{ Robust standard errors in parentheses } \\
\hline \multicolumn{4}{|c|}{$* * * \mathrm{p}<0.01, * * \mathrm{p}<0.05, * \mathrm{p}<0.1$} \\
\hline \multicolumn{4}{|c|}{$\begin{array}{l}\text { Note 1: The dependent variable is the industry-adjusted change in distance to default of the } \\
\text { acquiring firm. }\end{array}$} \\
\hline \multicolumn{4}{|c|}{$\begin{array}{l}\text { Note 2: } D D \text { is the distance to default of the respective firm (a higher value refers to a better } \\
\text { performing firm). }\end{array}$} \\
\hline
\end{tabular}

When deriving the fifth hypothesis we argued that in specific circumstances the default risk of the bidder could decrease when the target is riskier, for example, when a firm is acquired at a relative low premium due to its current financial and business difficulties and when the bidder feels comfortable to succeed in a turn-around of the target firm. A similar argument might be that a riskier target is very low valued and cheaper to acquire and therefore would lead to a smaller shift in asset allocation of the acquiring firm. Alternatively, it could be beneficial for the acquirer to merge with a riskier target, for example, when the target is smaller and the risk profile fits well with that of the acquirer, resulting in pronounced diversification effects. Table 16 shows some significant evidence for this hypothesis $(\beta=-0.039 ; \mathrm{p}=0.098)$. Therefore, the fifth hypothesis is supported. When the target has a lower distance to default, the default risk of the acquiring firm could decrease. This result is in line with previous research, 
e.g. by Bruyland and De Maeseneire (2016). Another reason for this result could be that the acquiring firm might gain more from tax benefits such as a large loss carry forward or high deductible interest payments. This can be due to high yield targets being, on average, higher levered than investment grade targets, as is presented in Table 9. These are all very special cases and examples. However, on average, we observe that the distance to default will decrease (the default risk will increase) after the merger, resulting often in negative long-run buy-and-hold abnormal returns.

From the sixth hypothesis, we expect that there is a positive relationship between geographical diversification and change in distance to default, meaning that a crossborder merger would decrease the default risk of the acquirer. The results in Table 16 indicate that the opposite is more likely $(\beta=-4.667 ; \mathrm{p}=0.012)$. This suggests that crossborder mergers are risk increasing, implying that it might be more challenging to assess the target's risk correctly, or harder to integrate a foreign target. It is necessary and important to distinguish between cross-border and cross-continent deals, due to potentially large cultural differences. Therefore, we also hypothesized that crosscontinent deals would be more diversifying and risk decreasing. In Table 15, we provide a significant indication supporting this part of the sixth hypothesis $(\beta=4.543$; $\mathrm{p}=0.012$ ). This might suggest that a cross-continent merger is indeed risk diversifying but could also mean that when a deal is cross-continental it mitigates the effect of the negative influence of cross-country mergers.

The seventh hypothesis suggests that if the bidder pays for a deal with cash, he is convinced that this deal is profitable, and that the merger should most likely decrease the default risk. In contrast, mergers are paid with shares of the bidder when the deal is much riskier and this should result in a higher default risk as the bidder attempts to share the risk with the shareholders of the target, which are becoming bidder shareholders. Table 16 reveals that there is a significant negative influence of share payment on the distance to default of the acquiring firm $(\beta=-5.104 ; p=0.011)$, thus supporting our hypothesis. This could mean that there is some risk transfer when shares are used as a payment method. The bidder and its shareholders try to share the risk of a possible difficult and often unsuccessful deal with the shareholders of the target. In addition, it can be observed from Table 15 that there is some form of negative and significant relationship between relative size and change in distance to 
default $(\beta=-0.005 ; p=0.083)$. This suggests that integrating a relatively smaller target should be less of a problem, but merging with a larger target is more complicated for the acquiring firm, resulting in a lengthier and more difficult process, which would result in a worse post-deal performance and thus an increase in default risk.

Above, we discussed all results on hypothesized relationships on the change in default risk. From the overall regression results, another interesting conclusion can also be drawn: the coefficient of the distance to default of the acquirer is highly significant and negative $(\beta=-0.281 ; p=0.000)$. An acquirer with a higher distance to default will have a larger decrease in distance to default from the merger or acquisition, increasing its default risk and vice versa. Risky acquirers might see a decrease in default risk surrounding the merger or acquisition. This can be driven by some form of diversification that is only applicable to these acquirers. We also ran the same regressions on a different time interval for the distance to default. The unpublished results are on average largely the same, but some results in the robustness test are less significant and the exploratory power of that model is lower. As another robustness test, we compared these regression results to the regression results of the Altman Z"'score. Both tests are available upon request.

The Altman Z' -score (Altman et al. 2014) for our sample is given by the following formula:

$$
Z^{\prime \prime}=6.56 X_{1}+3.26 X_{2}+6.72 X_{3}+1.05 X_{4}
$$

with $X_{1}$ being (current assets - current liabilities) / total assets, $X_{2}$ is the retained earnings / total assets, $\mathrm{X}_{3}$ is the EBIT / total assets and $\mathrm{X}_{4}$ is the book value of equity / total liabilities.

Table 17. Results for the change in Altman Z'-score of the acquiring firm

\begin{tabular}{|l|c|}
\hline & Acquirer \\
\hline Average change in Altman Z'-score & -0.227 \\
\hline t-statistic & -4.192 \\
\hline p-value & 0.000 \\
\hline $\mathrm{N}$ & 410 \\
\hline
\end{tabular}

Note: two-sided independent t-test conducted to test whether on average the change in Altman Z' -score is significantly different from 0 . 
The t-test in Table 17 suggests that there is a statistically significant decrease in the Altman Z"'-score due to the merger or acquisition, which can also be observed in figure 4. This is in line with the results for the distance to default from Table 14, which means that our results are rather robust to the model that is used to calculate the default risk.

Figure 4. Average Altman Z"-score of the acquiring firm, over the deal process

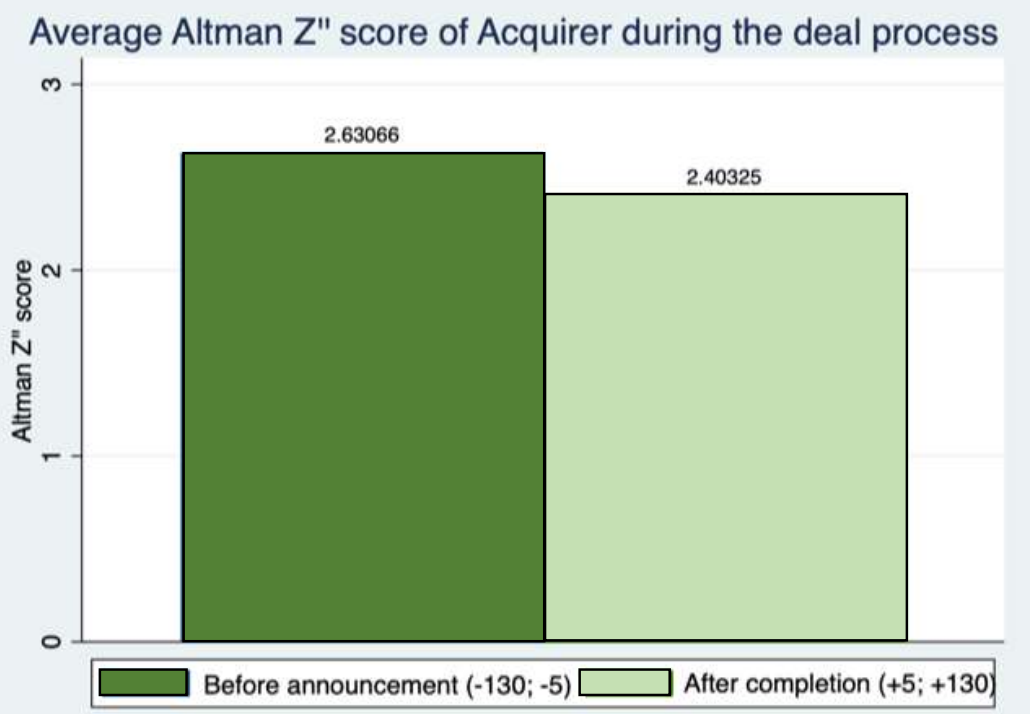

Note 1: This graph was constructed after winsorizing at the 1st and 99th percentile

Note 2: For the construction of this graph, the average of two periods were taken per firm, the 125 days leading up to 5 days before the announcement and the 125-day period 5 days after the completion of the deal. From these three averages, the average across the sample was calculated.

The regression results in Table 18 suggest overall the same direction of our findings as before, however, the significance differs. This could be caused by the difference in risk estimation methods between structural models (like the Merton model) or accounting-based (Altman Z') models. 
Table 18. OLS regression results for industry-adjusted change Altman Z''-score

\begin{tabular}{|c|c|c|}
\hline Variables & (1) & (2) \\
\hline \multirow[t]{2}{*}{ BHAR[-10; +10; announcement] acquirer } & -0.47700 & -0.50024 \\
\hline & $(0.63287)$ & $(0.69576)$ \\
\hline \multirow[t]{2}{*}{ BHAR[-10; +10; announcement] target } & $-0.34996^{*}$ & -0.23883 \\
\hline & $(0.20920)$ & $(0.23096)$ \\
\hline \multirow[t]{2}{*}{ Profit margin of Acquirer } & -0.42497 & -0.02957 \\
\hline & $(0.65113)$ & $(0.69531)$ \\
\hline \multirow[t]{2}{*}{ Profit margin of Target } & -0.01464 & -0.04330 \\
\hline & $(0.05027)$ & $(0.06780)$ \\
\hline \multirow[t]{2}{*}{ Days between announcement and completion } & $-0.00117 * *$ & $-0.00137 * *$ \\
\hline & $(0.00054)$ & $(0.00054)$ \\
\hline \multirow[t]{2}{*}{ Log of deal value } & -0.00671 & -0.02804 \\
\hline & $(0.02764)$ & $(0.03141)$ \\
\hline \multirow[t]{2}{*}{ Initial stake $(\%)$} & 0.24710 & 0.04463 \\
\hline & $(0.15644)$ & $(0.16415)$ \\
\hline \multirow[t]{2}{*}{ Payment dummy cash } & & $-0.44313 * *$ \\
\hline & & $(0.19616)$ \\
\hline \multirow[t]{2}{*}{ Payment dummy shares } & & -0.23233 \\
\hline & & $(0.16026)$ \\
\hline \multirow[t]{2}{*}{ Cross-country } & & -0.05262 \\
\hline & & $(0.12613)$ \\
\hline \multirow[t]{2}{*}{ Cross-continent } & & 0.06091 \\
\hline & & $(0.15926)$ \\
\hline \multirow[t]{2}{*}{ Relative Size } & & $-0.00026^{* * *}$ \\
\hline & & $(0.00010)$ \\
\hline \multirow[t]{2}{*}{ Relative Tobin's q } & & -0.00190 \\
\hline & & $(0.00379)$ \\
\hline \multirow[t]{2}{*}{ Z'’[-130; -5; announcement] acquirer } & & $-0.15027 * * *$ \\
\hline & & $(0.04246)$ \\
\hline \multirow[t]{2}{*}{ Z'’[-130; -5; announcement] target } & & 0.02630 \\
\hline & & $(0.01725)$ \\
\hline \multirow[t]{2}{*}{ Constant } & 0.29562 & $1.53390 * *$ \\
\hline & $(0.54425)$ & $(0.60019)$ \\
\hline
\end{tabular}


Table 18. Cont. ...

\begin{tabular}{|c|c|c|}
\hline Observations & 410 & 376 \\
\hline Adjusted R-squared & 0.0144 & 0.1064 \\
\hline F-statistic & 2.26 & 4.08 \\
\hline \multicolumn{3}{|c|}{ Robust standard errors in parentheses } \\
\hline \multicolumn{3}{|c|}{$* * * \mathrm{p}<0.01, * * \mathrm{p}<0.05, * \mathrm{p}<0.1$} \\
\hline \multicolumn{3}{|c|}{ Note 1: The dependent variable is the Industry adjusted change in Altman Z'-score of the acquirer } \\
\hline \multicolumn{3}{|c|}{$\begin{array}{l}\text { Note 2: Z' is the Altman Z' '-score of the respective firm (a higher value on this variable means better } \\
\text { performing firm). }\end{array}$} \\
\hline \multicolumn{3}{|c|}{$\begin{array}{l}\text { Note 3: All variables are either the mean from the period surrounding the announcement date, which } \\
\text { is shown by the number of business days in the brackets, or at announcement date. }\end{array}$} \\
\hline \multicolumn{3}{|c|}{$\begin{array}{l}\text { Note 4: BHAR is the Buy and Hold abnormal return of the 20-day period surrounding the } \\
\text { announcement period. }\end{array}$} \\
\hline
\end{tabular}

\section{Conclusion}

The objective of this study was to examine the influence of a merger or acquisition on the default risk of the acquiring firm. Below, we first summarize the results of our study and then continue providing some suggestions for future research in this still less studied area.

\section{Summary of the study}

While there is an ambiguity in prior studies on distance to default, an apparent influence of the distance to default on the buy-and-hold abnormal return (BHAR) can be noticed surrounding the announcement date. To analyse this relationship, an adoption of the Merton distance to default model was used to calculate scores for all acquiring and target companies. The hypothesized relationships were tested with ttests for different subsamples as well as with regression analyses. The data set consists of a sample of 531 deals that were completed between the $1^{\text {st }}$ of October 1998 and the $5^{\text {th }}$ of March 2018, and in which the bidder firms were from Europe but the target firms could be from any countries around the world.

The results from our analysis of the cumulative abnormal returns were compared to the results from previous studies. As in most of these studies, our analysis finds for the target firms, on average, significantly positive CARs and for the acquiring firms 
only CARs that are insignificantly different from zero. When analysing the buy-andhold abnormal returns (BHARs), two observations are important. First, an underperformance with the target is visible after the third day subsequent to the announcement. It may be that M\&A announcements in our sample are first overpriced during the announcement period. Therefore, the initial outperformance overshoots and is too high, leading to a reversal and a small market performance decline later on. The second but important finding of this analysis is the negative effect of distance to default of the target on the buy-and-hold abnormal return of the target. Analysing this effect was our main motivation and initiation for this study.

On average, we observe for our sample that mergers and acquisitions increase the default risk of the acquiring firm. This means that some mergers might decrease this risk but most often, the default risk is higher after the M\&A, which is consistent with the poor stock price performance of many deals post M\&A. Many explanations and reasons for this observation were already suggested in the literature and empirically tested. Firms and managers might be considering alternatives to avoid this effect by acquiring only firms that offer great synergies or diversification effects, by not overpaying for targets, by having a sound financing of the deal and not overextending its own debt capacity, by staying away from mergers among equals, and by acquiring defaulting targets only if a turnaround seems very likely.

We hypothesised that geographical diversification would decrease the default risk. However, for our sample, we reject this hypothesis and provide significant support for the opposite hypothesis: in cross-country deals the default risk increases, on average. However, what does help in diversifying the default risk, is acquiring a target that is situated on a different continent. This suggests that a cross-continent merger is indeed risk diversifying, but it could also mean that when the deal is crosscontinent it mitigates the negative effect of cross-country mergers.

The next relationship that we analysed was that mergers that are partially paid with shares would increase the default risk. In contrast, when cash was used as a payment method, it would decrease default risk. From the overall regression, it became evident that share payments increased the default risk and cash payments had no significant effect. The hypothesis stating that relative size between the target and the acquirer would be negatively related to the change in distance to default was 
supported. This suggests that relatively larger target firms such as mergers among equals are more complicated to integrate into the acquiring firm.

\section{Future research implications}

In our research, we analyze the changes in distance to default and default probability for European bidder firms before and subsequent to engaging in a merger or acquisition. A general set of variables is used to determine the changes in default risk. We observe high abnormal returns and high premiums for target firms around the M\&A announcement, suggesting that most M\&A related synergy gains are absorbed by the target shareholders. Moreover, insignificant stock price reaction in the periods prior and after the announcement indicate that the markets are highly efficient. All hypothesized relationships on the changes in default risk are tested via a regression analysis. Further, we analyze our results in more detail by investigating which factors explain the increase in default risk. The main finding of our empirical analysis is that, on average, mergers and acquisitions of European bidders significantly increase the default risk during the post-merger period. Moreover, we extend the literature by providing new empirical evidence that some observed relationships and determinants are different for Europe relative to the United States.

The findings from our research and the developed approach could be employed to predict the bidder performance subsequent to an M\&A deal by analyzing the change in default risk of the bidder firm. This result might be of interest to managers and shareholders of bidder and target firms as well as to investment bankers, corporate finance advisors and to asset managers and individual investors as it provides some possible explanations for the average increase in default risk. It also offers some explanations why firms are still engage in certain deals even though the market predicts that the default risk, on average, might increase. As most of the literature suggests that a large number of M\&A deals do not create shareholder value in the long-run, this research could be extended by relating the default risk measures to the long-run performance and performance differences. 


\section{Wolfgang BESSLER, Hidde STEENBEEK, Wim WESTERMAN}

\section{References}

Alexandridis G., Mavrovitis Ch.F., Travlos N.G. (2012), How have M\&As changed? Evidence from the sixth merger wave, "The European Journal of Finance”, vol. 18, pp. 663-688.

Alexandridis G., Petmezas D., Travlos N.G. (2010), Gains from mergers and acquisitions around the world: new evidence, "Financial Management", vol. 39 no. 4, pp. 1671-1695.

Altman E.I., Iwanicz-Drozdowska M., Laitinen E.K., Suvas A. (2014), Distressed firm and bankruptcy prediction in an international context. A review and empirical analysis of Altman's z-score model, https://papers.ssrn.com/sol3/papers.cfm?abstract_id=2536340 [12.12.2019].

Amihud Y., Lev B. (1981), Risk reduction as a managerial motive for conglomerate mergers, "Bell Journal of Economics", vol. 12 no. 2, pp. 605-617.

Antoniou A., Arbour P., Zhao H. (2008), How much is too much. Are merger premiums too high? "European Financial Management", vol. 14 no. 2, pp. 268-287.

Arık E., Kutan A.M. (2015), Do mergers and acquisitions create wealth effects? Evidence from twenty emerging markets, "Eastern European Economics", vol. 53 no. 6, pp. 529-550.

Asquith P., Bruner R.F., Mullins D.W. Jr (1983), The gains to bidding firms from merger, "Journal of Financial Economics", vol. 11 no. 1-4, pp. 121-139.

Bessler W., Drobetz W., Zimmermann J. (2011), Financing corporate mergers and acquisitions, in: Capital structure and corporate financing decisions. Theory, evidence and practise, Baker H.K., Martin G. (eds.) (Kolb Series in Finance), John Wiley \& Sons, Hoboken, NJ, pp. 419-444.

Bessler W., Schneck C. (2015), Excess premium offers and bidder success in European takeovers, "Eurasian Economic Review", vol. 5 no. 1, pp. 23-62.

Bessler W., Schneck C. (2016), Excess takeover premiums and bidder contests in Merger \& Acquisitions. New methods for determining abnormal offer prices, in: Analysis of large and complex data, Wilhelm A.F.X., Kestler H.A. (eds.), Springer, Berlin-Heidelberg, pp. 323-333.

Bessler W., Schneck C., Zimmermann J. (2015), Bidder contests in international mergers and acquisitions. The impact of toeholds, preemptive bidding, and termination fees, "International Review of Financial Analysis", vol. 42, pp. 4-23.

Bharath S.T., Shumway T. (2008), Forecasting default with the Merton distance to default model, "The Review of Financial Studies", vol. 21 no. 3, pp. 1339-1369.

Billett M.T., King T.-H.D., Mauer D.C. (2004), Bondholder wealth effects in mergers and acquisitions. New evidence from the 1980s and 1990s, "The Journal of Finance", vol. 59 no. 1, pp. 107-135.

Black F., Scholes M. (1973), The pricing of options and corporate liabilities, "Journal of Political Economy”, vol. 81 no. 3, pp. 637-654.

Brown S.J., Warner J.B. (1985), Using daily stock returns. The case of event studies, "Journal of Financial Economics", vol. 14 no. 1, pp. 3-31. 
Bruyland E., De Maeseneire W. (2016), The risk effects of acquiring distressed firms, "Journal of Business Finance \& Accounting", vol. 43 no. 9-10, pp. 1297-1324.

Bureau van Dijk (2018), Global M\&A review 2018, Bureau van Dijk, https://www.bvdinfo.com/BvD/media/reports/Global-M-A-Review-2018.pdf [12.12.2019].

Cornett M.M., Tanyeri B., Tehranian H. (2011), The effect of merger anticipation on bidder and target firm announcement period returns, "Journal of Corporate Finance”, vol. 17 no. 3, pp. 595-611.

Dezsö C.L., Ross D.G. (2012), Does female representation in top management improve firm performance? A panel data investigation, "Strategic Management Journal”, vol. 33 no. 9, pp. 1072-1089.

Dong M., Hirshleifer D., Richardson S., Teoh S.H. (2006), Does investor misvaluation drive the takeover market? "The Journal of Finance", vol. 61 no. 2, pp. 725-762.

Furfine C.H., Rosen R.J. (2011), Mergers increase default risk, "Journal of Corporate Finance", vol. 17 no. 4 , pp. 832-849.

Ghosh A., Jain P.C. (2000), Financial leverage changes associated with corporate mergers, "Journal of Corporate Finance", vol. 6 no. 4, pp. 377-402.

Hackbarth D., Morellec E.E. (2008), Stock returns in mergers and acquisitions, "The Journal of Finance”, vol. 63 no. 3 , pp. $1213-1252$.

Ishii J., Xuan Y. (2014), Acquirer-target social ties and merger outcomes, "Journal of Financial Economics", vol. 112 no. 3, pp. 344-363.

Jensen M.C. (1986), Agency costs of free cash flow, corporate finance, and takeovers, "The American Economic Review", vol. 76 no. 2, pp. 323-329.

Jensen M.C. (2005), Agency costs of overvalued equity, "Financial Management”, vol. 34 no. 1, pp. 519.

Kaldor N. (1966), Marginal productivity and the macro-economic theories of distribution. Comment on Samuelson and Modigliani, "Review of Economic Studies", vol. 33 no. 4, pp. 309-319.

Kedia S., Zhou X. (2014), Informed trading around acquisitions. Evidence from corporate bonds, "Journal of Financial Markets", vol. 18 no. C, pp. 182-205.

Kiymaz H., Baker H.K. (2008), Short-term performance, industry effects, and motives. Evidence from large M\&As, "Quarterly Journal of Finance and Accounting", vol. 47 no. 2, pp. 17-44.

Koerniadi H., Krishnamurti Ch., Tourani-Rad A. (2015), Cross-border mergers and acquisitions and default risk, "International Review of Financial Analysis", vol. 42, pp. 336-348.

Lang L., Stulz R., Walkling R.A. (1989), Managerial performance, Tobin's Q, and the gains from successful tender offers, "Journal of Financial Economics", vol. 24 no. 1, pp. 137-154.

Lattanzio G., Megginson W.L., Sanati A. (2019), Listing gaps, merger waves, and the privatization of American equity finance, https://papers.ssrn.com/sol3/papers.cfm?abstract_id=3329555 [12.12.2019]. 
Liao H.H., Chen T.-K., Lu Ch.-W. (2009), Bank credit risk and structural credit models. Agency and information asymmetry perspectives, "Journal of Banking \& Finance", vol. 33 no. 8, pp. 1520-1530.

Maksimovna K.M. (2015), Influence of mergers and acquisitions on the default risk of the acquiring firm, "European Journal of Economics and Management Sciences", no. 3, pp. 70-73.

Merton R.C. (1974), On the pricing of corporate debt. The risk structure of interest rates, "The Journal of Finance", vol. 29 no. 2, pp. 449-470.

Mitchell M., Andrade G., Stafford E. (2001), New evidence and perspectives on mergers, "Journal of Economic Perspectives", vol. 15 no. 2, pp. 103-120.

Moeller S.B., Schlingemann F.P., Stulz R.M. (2004), Firm size and the gains from acquisitions, "Journal of Financial Economics", no. 73, pp. 201-228.

Moeller S.B., Schlingemann F.P., Stulz R.M. (2005), Wealth destruction on a massive scale? A study of acquiring-firm returns in the recent merger wave, "The Journal of Finance", vol. 60 no. 2, pp. 757-782.

Pelow S., Nguyen H.H. (2018), Distressed mergers and acquisitions, MSc Thesis in Accounting \& Finance, Lund University School of Economics and Management.

Savor P.G., Lu Q. (2009), Do stock mergers create value for acquirers? “The Journal of Finance”, vol. 64 no. 3, pp. 1061-1097.

Schwert G.W. (1996), Markup pricing in mergers and acquisitions, "Journal of Financial Economics", vol. 41 no. 2 , pp. $153-192$.

Tang Z., Xu X. (2016), What causes the target stock price run-up prior to M\&A announcements? "Journal of Accounting and Finance", vol. 16 no. 6, pp. 106-120.

Tobin J. (1969), A general equilibrium approach to monetary theory, "Journal of Money, Credit and Banking", vol. 1 no. 1, pp. 15-29.

Wang C., Xie F. (2008), Corporate governance transfer and synergistic gains from mergers and acquisitions, "The Review of Financial Studies", vol. 22 no. 2, pp. 829-858.

Y1lmaz I.S., Tanyeri B. (2016), Global merger and acquisition (M\&A) activity: 1992-2011, "Finance Research Letters", vol. 17 no. C, pp. 110-117.

Yook K.C. (2003), Larger return to cash acquisitions. Signaling effect or leverage effect?, "The Journal of Business", vol. 76 no. 3, pp. 477-498. 


\section{Appendix: Measuring the distance to default (DD)}

The moment a firm default on its debt can be assumed to occur on the maturity date of the debt, if the face value of the debt is higher than the firm's value (Merton 1974). Shareholders have a residual claim on the assets when all debt is repaid in full. This resembles a European call option with a strike price equal to the face value of the debt. For the pricing of this European call option, the model by Black and Scholes (1973) is used, see equation A1 - A3.

$$
\begin{aligned}
& C=S * N\left(d_{1}\right)-N\left(d_{2}\right) X e^{-r t} \\
& d_{1}=\frac{\ln (S / X)+\left(r+s^{2} / 2\right) t}{S * \sqrt{t}} \\
& \mathrm{~d}_{2}=\mathrm{d}_{1}-\mathrm{s}^{*} \sqrt{\mathrm{t}}
\end{aligned}
$$

with $C$ being the price of the call option, $S$ being the current price of the underlying asset, $t$ being the time until expiration, $r$ being the risk-free interest rate, $X$ being the strike price of the option, $\mathrm{s}$ being the volatility of the underlying asset and $N$ being a cumulative standard normal distribution (Black and Scholes, 1973). From this, Merton (1974) derived his distance to default (DD) model. This model has some assumptions, the first being that total firm value follows a geometric Brownian motion. This is a continuous-time stochastic process where the logarithm of the randomly varying quantity moves in a Brownian motion (Bharath, Shumway 2008).

$$
d V=\mu V d t+\sigma_{V} V d W
$$

In equation A4, $V$ is the total firm value, $\mu$ is a drift constant represented by the return on assets of the firm (ROA), $\sigma_{V}$ is the volatility of the firm value and $d W$ is a standard Wiener Process (Bharath, Shumway 2008). Another important assumption of the Merton DD model is that the firm has issued only one discount bond, which matures in time T. These assumptions lead to the comparison with a European call option, as described above. From these assumptions and the Black and Scholes model, Merton (1974) formulates the market value of equity as follows, see equation A5. 


$$
E=V * N\left(d_{3}\right)-N\left(d_{4}\right) F e^{-r}
$$

In this equation, $E$ is the market value of equity, or the market capitalization of the firm, $d_{3}$, is given by equation A6, $r$ is the risk-free interest rate, $F$ is the face value of debt of the firm, $N$ is a cumulative standard normal distribution and $d_{4}$ is given by equation $\mathrm{A} 7$.

$$
\begin{aligned}
& d_{3}=\frac{\ln (V / F)+\left(r+\sigma_{V / 2}^{2}\right) T}{\sigma_{V} * \sqrt{T}} \\
& d_{4}=d_{3}-\sigma_{V} \sqrt{T}
\end{aligned}
$$

The Merton DD model assumes that equity value is a function of firm value and time. It is assumed that equity follows a continuous-time stochastic process, which can be described via calculus by Itô's lemma (Bharath, Shumway 2008). From this follows equation $\mathrm{A} 8$.

$$
\sigma_{E}=\left(\frac{V}{E}\right) N\left(d_{1}\right) \sigma_{V}
$$

From this, several steps are taken in the Merton DD model to arrive at the distance to default. First, $\sigma_{E}$ must be estimated from option-implied volatility or historical stock returns. Second, a forecasting horizon $(T)$ and a measure of the face value of debt have to be chosen. A general choice is to estimate $\sigma_{E}$ from historical data, use an assumed time to maturity of the liabilities of 1 year and use the book value of total liabilities from the balance sheet of the firm as proxy for the market value of debt (Bharath, Shumway 2008).

Third, data should be collected, the methods and sample descriptive statistics are explained in the main text. The fourth step is to find $V$ and $\sigma_{V}$ by iteratively solving equation $\mathrm{A} 5$. When these four steps have been undertaken, distance to default is given by the following equation, A9. 


$$
D D=\frac{\ln (V / F)+\left(\mu-0.5 \sigma_{V}^{2}\right) T}{\sigma_{V^{*} \sqrt{T}}}
$$

From the distance to default the probability of default can be obtained by using a standard normal cumulative distribution (Bharath, Shumway 2008). This is a just an approximation though, since the cumulative distance to default will not be normally distributed (Furfine, Rosen 2011).

For the analysis, the mean of the 125 days preceding the fifth day before the announcement is taken, as well as the mean of the 125 days after the fifth day following the completion of the merger or acquisition. These time frames are chosen because of the observed and tested run-up period in the market surrounding the announcement. A number of robustness tests are conducted to check for robustness of this chosen timeframe. These tests are available from the authors upon request. They provide overall the same main results.

From the distance to default mean a difference term $(\Delta \mathrm{DD})$ is calculated. This term is industry adjusted (as $\triangle \mathrm{IADD}$ ) by computing the difference between the mean DD change of the industry and the DD change term of the firms. This is done to adjust for time and inter-industry effects. The calculation is shown in the formulas below.

$$
\begin{aligned}
& \Delta D D_{i}=D D_{(+5 ;+130 ; \text { completion }), i}-D D_{(-13 ;-5 ; \text { announcement }), i} \\
& \Delta I A D D_{i}=\Delta D D_{i}-\overline{\Delta D D_{\text {industry }}}
\end{aligned}
$$

